\title{
UN PRIMER AVANCE PARA UN FUTURO ACUERDO ENTRE CHILE Y la SANTA SEDE (I): UNA PROPUESTA DE CLÁUSUlaS CONCORDATARIAS A PARTIR DE LAS MATERIAS REGULADAS EN LOS PROYECTOS DE CONCORDATO PREPARADOS EN CHILE EN 1928*
}

\section{Carlos Salinas ARANEdA**}

RESUMEN: Con ocasión de la separación entre la Iglesia y el Estado regulada en la Constitución de 1925 hubo conversaciones tendientes a la celebración de un concordato entre el Estado de Chile y la Santa Sede, pero se ha desconocido hasta ahora la existencia de proyectos concretos encaminados a este fin. La reciente apertura del Archivo Secreto Vaticano en lo referido a los fondos del pontificado del papa Pío XI ha permitido conocer los borradores que se redactaron en dicha oportunidad con la finalidad de llegar a un acuerdo internacional de esa naturaleza. A partir de las materias reguladas en dichos proyectos se proponen los que podrían ser algunos de los contenidos de un futuro concordato entre Chile y la Santa Sede.

PALABRAS CLAVE: Concordato - relaciones Iglesia-Estado en Chile Acuerdo Chile-Santa Sede - Proyecto de concordato

\section{A FIRST REVIEW FOR A FUTURE AGREEMENT BETWEEN CHILE AND THE HOLY SEE (I): A PROPOSAL OF CONCORDAT TERMS FROM SUBJECTS REGULATED IN THE CONCORDAT PROJECTS PREPARED IN CHILE IN 1928}

ABSTRACT: Due to the separation between the Church and the State regulated by the Constitution of 1925 conversations took place, in order to

Esta investigación ha sido realizada con ocasión del Proyecto Fondecyt regular 1120345, "El pretendido concordato de 1925 entre Chile y la Santa Sede: historia y proyecciones actuales" del que su autor es investigador responsable.

Fecha de recepción: 10 de marzo de 2014.

Fecha de aceptación: 25 de noviembre de 2014.

** Catedrático de Historia del Derecho y Derecho Canónico en la Facultad de Derecho de la Pontificia Universidad Católica de Valparaíso (CHILE). Doctor en derecho por la Universidad Complutense de Madrid (España). Doctor en Derecho Canónico por la Pontificia Universidad Santo Tomas in Urbe, Angelicum, Roma (ItaLia). Correo electrónico: csalinas @ucv.cl 
celebrate a concordat between the Chilean State and the Holy See, but until now the existence of concrete projects aimed at this end were unknown. The recent opening of the Vatican Secret Archive, with reference to the funds of Pope Pius XI's pontificate, has enabled the knowledge of the drafts written on that occasion, with the intention of reaching such an international agreement. As of the topics regulated in the projects, the possible contents for a future concordat between Chile and the Holy See are proposed.

KEY WORDS: Concordat - State-Church relations in Chile - ChileHoly See agreement - project for a concordat

Sumario: Introducción. 1) Libertad y autonomía de la Iglesia. 2) Personalidad juridica. 3) Régimen patrimonial. 4) Régimen tributario. 5) Libre comunicación con Roma. 6) Resguardo del orden en actos público. 7) Exenciones de los clérigos. (7.1.) Servicio militar. (7.2.) Cargos y oficios públicos ajenos al estado clerical. 8) Inmunidad de edificios religiosos. 9) Asistencia religiosa a las Fuerzas Armadas. 10) Matrimonio canónico. 11) Obispado cuyo obispo resida fuera de Chile. 12) Creación de beneficios eclesiásticos y comunidades religiosas. 13) Nombramiento de obispos. 14) Enseñanza religiosa. 15) Actos administrativos sobre bienes eclesiásticos. 16) Acusaciones contra eclesiásticos por delitos comunes. 17) Cláusulas finales. Anexo. Avance de un acuerdo entre Chile y la Santa Sede. Bibliografía.

\section{INTRODUCCIÓN}

A mediados del año 2006 el papa Benedicto XVI dispuso la apertura del Archivo Secreto Vaticano en lo relativo a los fondos del pontificado de Pío XI ${ }^{1}$ que, iniciado el 6 de febrero de 1922, se extendió hasta el 10 de febrero de 1939, lo que ha permitido conocer los tres proyectos que se redactaron en 1928 con la finalidad de celebrar un concordato entre Chile y la Santa Sede. En efecto, con ocasión de la separación entre la Iglesia y el Estado sancionada en la Constitución de $1925^{2}$ se habló de la posibilidad de celebrar un acuerdo de esta naturaleza, lo que no era una novedad

1 Bolletino della Sala Stampa della Santa Sede, 30 junio 2006 no 0340, en www.vatican.va [consultado el 24 de mayo de 2011].

2 Acerca de la separación Iglesia-Estado en Chile puede verse la bibliografía que incluyo en Salinas Araneda, Carlos (2000) "Ensayo de una bibliografía de derecho eclesiástico del Estado de Chile". Revista de Derecho de la Universidad Católica de Valparaíso No 21, pp. 131165 = Revista Española de Derecho Canónico No 152 (2002), pp. 263-295, actualizada en ÉL mismo (2004) Lecciones de derecho eclesiástico del Estado de Chile. Valparaíso: Ediciones Universitarias de Valparaíso, 474 pp., 423-458, esp. 435-436. Se puede agregar Pacheco Gómez, Máximo (2004) La separación de la Iglesia y el Estado en Chile y la diplomacia vaticana. 
en la historia patria porque durante el siglo anterior había habido intentos, llevados adelante por Chile, para celebrar un concordato con la Santa Sede, ninguno de los cuales llegó a materializarse en un texto concreto ${ }^{3}$. La idea sugerida en 1925, sin embargo, no se llevó delante de inmediato, en parte, porque como cuenta Oviedo Cavada ${ }^{4}$, la Santa Sede puso cinco condiciones para convenir en la separación que se solicitaba ${ }^{5}$, todas las cuales se cumplieron con la excepción de la celebración del concordato, pues el presidente Alesandri habría hecho ver la carencia de tiempo para una gestión de esa envergadura, interesado, como estaba, en aprobar prontamente la nueva Constitución. La idea, sin embargo, no fue abandonada por la Santa Sede la que, aprovechando la llegada de un nuevo nuncio a Chile, don Ettore Felici ${ }^{6}$, insistió en la posibilidad de llegar a un acuerdo con el gobierno de Chile.

El gobierno de Chile acogió la invitación y el martes 1 de mayo de 1928, el embajador de Chile ante la Santa Sede hizo entrega de un proyecto de concordato, diciendo que tenía instrucciones de pedir el parecer de la Secretaría de Estado, como quedó consignado en un pro memoria redactado al día siguiente, el 2 de mayo, por el cardenal secretario de Estado, texto en el que se agregaba que dicho secretario había examinado el proyecto de concordato y había hecho relación de él al Santo Padre. A este proyecto le denominó Proyecto I7 . Poco después, el miércoles 23 de mayo, el ministro de Relaciones Exteriores de Chile, Conrado Ríos Gallardo, hizo entrega al nuncio en Santiago de un segundo texto, que, basado en el primero, introducía algunas modificaciones en el sentido de dar mayor injerencia al Estado en los asuntos eclesiásticos. A este texto le denominó el Proyecto II. Al hacer entrega del mismo, el ministro había

Santiago: Editorial Andrés Bello, 333 pp.; respecto de este libro se puede ver mi recensión en Revista de Estudios Histórico-Juridicos 27 (2005), pp. 562-564.

3 Oviedo Cavada, Carlos (1958) "Negociaciones chilenas sobre convenios con la Santa Sede". Finis Terrae. No 9, pp. 37-53; Oviedo Cavada, Carlos (1962) La misión Irarrázabal en Roma 1847-1850. Estudio histórico-canónico de las relaciones de Iglesia y Estado en Chile. Santiago: Ediciones Universidad Católica de Chile, 450 pp.; Oviedo Cavada, Carlos (1987) "Un siglo de relaciones entre la Santa Sede y Chile. 1822-1925”. Diplomacia. No 39, pp. 18-30.

4 Oviedo Cavada, Carlos (1975-1976) "La jerarquía eclesiástica y la separación de la Iglesia y el Estado en 1925”. Boletín de la Academia Chilena de la Historia. No 89, pp. 13-22.

5 Las condiciones eran: i) Chile no debía convertirse en Estado ateo y, por eso, habría de obtenerse la invocación del nombre de Dios en la promulgación de la nueva Constitución; ii) la libertad de enseñanza para dar cabida a la educación particular y que, en ciertos tipos de enseñanza, se indicara su obligatoriedad, sin añadir la palabra "laica”; iii) derogación expresa de todos los abusos regalistas de la Constitución de 1833, como el patronato, el pase regio, etc.; iv) entre los pactos internacionales había de hacerse expresa mención de los concordatos; v) la celebración de un concordato y una compensación económica del Estado al suprimir el presupuesto del culto.

6 Sus datos biográficos en Ducasse Medina, Ignacio (2008) Servidores del Evangelio. Los obispos de Chile 1561-2007. Santiago: Conferencia Episcopal de Chile, 342 pp., pp. 154-155.

7 Salinas Araneda, Carlos (2012) "Un primer proyecto de concordato entre Chile y la Santa Sede en 1928”. Revista Chilena de Derecho. vol. 39 No 3, pp. 665-698. 
solicitado al nuncio que, una vez revisado su contenido, se lo devolviera con sus observaciones. Como el nuncio advirtió en dicho proyecto artículos que limitaban la libertad de la Iglesia, redactó un nuevo texto completo, al que denominó Proyecto III.

En las páginas que siguen, a partir de los contenidos de dichos proyectos, formulo un primer avance de lo que, en mi opinión, debería ser el contenido de un eventual futuro concordato entre Chile y la Santa Sede. Se trata de la primera vez que en la literatura jurídica chilena se hace una formulación similar, sobre una materia que requiere un análisis reposado y pormenorizado, razón por la que se trata de un primer avance sobre la materia. Para su lectura es preciso, en todo caso, tener presente lo siguiente: i) la propuesta arranca de unos textos concretos, esto es, los proyectos que se redactaron en 1928 por las dos partes protagonistas de un acuerdo de esta naturaleza. La razón de ello no solo es el afán de mantener una continuidad histórica con dichos proyectos, sino también por el hecho de que las materias que interesan al Estado y a la Iglesia, tradicionalmente denominadas materias mixtas, son las mismas a lo largo del tiempo, por lo que un acuerdo en estos tiempos no abordará materias muy diversas a las recogidas en dichos proyectos; ii) no todo lo contenido en los proyectos de 1928 queda recogido en las páginas que siguen, pues hay en ellos materias que el inexorable paso del tiempo ha ido dejando de lado. Ello es notorio en lo que se refiere a los intentos del Estado de Chile de retomar algunas facultades intervencionistas al interior de la Iglesia, propias de un sistema de patronato que había quedado definitivamente superado en 1925, facultades que el gobierno se resistía a perder, no obstante haber sido el impulsor de la separación entre los poderes espiritual y temporal en Chile; iii) hay materias que, interesando en la actualidad, no están contempladas en los proyectos de 1928, materias que han ido cobrando importancia en los años posteriores, como la asistencia religiosa en las cárceles y centros de salud, o la conservación del patrimonio históricoartístico; dichas materias, que aparecen regularmente en los concordatos contemporáneos, no son abordadas en esta páginas cuyo origen está en unos proyectos concretos, además de que habría significado una extensión desmesurada de ellas, por lo que serán abordadas en otro trabajo. Queda claro, en consecuencia, que este avance de acuerdo entre Chile y la Santa Sede es parcial; iv) el criterio utilizado para redactar este avance es el de recoger por escrito lo que ya contempla nuestra legislación nacional a propósito de las diversas materias tratadas. No se trata de pedir privilegios especiales para la Iglesia católica, sino que se trata de que, a la luz del derecho de libertad religiosa reconocido en nuestra Constitución y en el Concilio Vaticano II $^{8}$, se permita a la Iglesia llevar adelante la tarea que le

8 Concilio Vaticano II (1965) Declaración 'Dignitatis humanae', sobre la libertad religiosa. $\mathrm{Su}$ texto en castellano en Concilio Vaticano II (1997) Constituciones, decretos, declaracio- 
es propia, que no es otra que la de que las almas tengan vida y la tengan en abundancia; v) en la redacción de los artículos del avance que propongo he tenido a la vista los no pocos concordatos celebrados por la Santa Sede a partir del Concilio Vaticano II, pero no he dejado constancia de esta circunstancia porque la extensión de estas páginas me lo ha impedido; a ellos me he referido pormenorizadamente al hacer la presentación y análisis del Proyecto III, que está en prensas; vi) en el anexo final a estas páginas recojo unitariamente las diversas propuestas que hago en la medida que avanzo en el estudio de las diversas materias; este análisis lo he hecho siguiendo el orden en que las mismas son abordadas los proyectos, pero el proyecto final lo he ordenado de una manera diversa, que me ha parecido más ordenada.

\section{1) LIBERTAD Y AUTONOMÍA DE LA IGLESIA}

Según el artículo 1 de los Proyectos I y II, "La Iglesia Católica gozará en el territorio de la República de Chile de plena libertad y podrá erigir y conservar templos y sus dependencias con las condiciones de seguridad e higiene fijadas por las leyes y ordenanzas que rijan en Chile sobre la materia". En el Proyecto III, el nuncio le daba una nueva redacción: "La Iglesia Católica gozará en el territorio de la República de Chile de plena independencia en el ejercicio de su ministerio espiritual, y de todas las libertades necesarias para el cumplimiento de su divina misión". El nuncio agregaba a la "libertad" la "independencia", y eliminaba la referencia a la erección y conservación de templos, proporcionando al artículo un contenido homogéneo.

Después que se reconociera el derecho de libertad religiosa en el Concilio Vaticano II, la Iglesia ha dejado de impetrar privilegios, limitándose tan solo a pedir que los Estados, en cumplimiento de la libertad religiosa que proclaman normalmente en sus Constituciones, le permitan ejercer con libertad la misión espiritual que le es propia, en igualdad de condiciones con las otras confesiones religiosas; no más derechos que ellas, pero tampoco menos.

La falta de un concordato no ha impedido que la Iglesia católica haya podido disfrutar en Chile de libertad e independencia en el ejercicio de su misión bajo la vigencia de las Constituciones de 1925 y 1980 . Mejor aún, la separación entre la Iglesia y el Estado sancionada en la primera de ellas y reiterada en la segunda le ha permitido disfrutar de una libertad que no tenía bajo la vigencia de la Constitución de 1833 y a la que aspiraba. Esta libertad ha venido a reiterarse con la ley $19.638^{9}$ con la cual

nes, legislación posconciliar. $4^{\mathrm{a}}$ Ed. Madrid: Biblioteca de Autores Cristianos, 1129 pp., pp. 778-804.

$9 \quad$ Publicada en Diario Oficial de 14 de octubre de 1999. 
se ha desarrollado en Chile el derecho de libertad religiosa, cuyo artículo 7 , en el que se enuncian algunas de las facultades colectivas que otorga dicho derecho, se inicia con una afirmación contundente: "en virtud de la libertad religiosa y de culto se reconoce a las entidades religiosas plena autonomía para el desarrollo de sus fines propios". El mismo artículo enuncia algunas de dichas facultades colectivas (arts. 7-8) todas las cuales son expresión de esa libertad confirmada con tanta claridad.

El artículo proyectado en 1928 es una norma que, de cara a un futuro concordato, deberá estar presente y cuya fórmula no ofrece muchas dificultades. Me parece que la redacción que se ha dado al artículo 2 del reciente acuerdo con Brasil ${ }^{10}$ puede iluminar nuestra redacción la que, utilizando el lenguaje de nuestra ley, puede quedar en estos términos: "\$1. La República de Chile, sobre la base del derecho de libertad religiosa, reconoce a la Iglesia católica el derecho de desarrollar con plena autonomía su misión apostólica, garantizando el ejercicio público de sus actividades, en conformidad con el ordenamiento jurídico chileno.

Este artículo, así concebido, sin embargo, garantiza el libre actuar de la Iglesia ad-extra de ella misma, es decir, le garantiza el cumplimiento libre, al interior de la sociedad chilena, de la misión que le es propia, salvo las limitaciones que arranquen de la moral, de la buenas costumbre y del orden público, pero no le garantiza la plena libertad y autonomía ad-intra, esto es, al interior de ella respecto de la intervención eventual de los poderes del Estado, por lo que el reconocimiento de esa libertad y autonomía es preciso que también se reconozca. Es lo que hacía el Proyecto I cuando, en su artículo 2, disponía que "El gobierno de Chile asegura a la Iglesia y a los organismos que de ella dependen el libre ejercicio de su poder espiritual $y$ de su jurisdicción eclesiástica, lo mismo que la libre administración de sus bienes y negocios, conforme al derecho canónico y a las leyes chilenas", artículo que, al pasar al Proyecto II aparecía complementado con una frase ańadida al final: "en cuanto no se oponga a las leyes chilenas", y que en el proyecto del nuncio aparecía reformulado, vinculándolo con la personalidad jurídica de la Iglesia, en los siguientes términos: "El Gobierno de Chile asegura a la Iglesia católica, en los organismos que de ella dependen según el derecho canónico, el libre ejercicio de su poder espiritual y de su jurisdicción eclesiástica, $y$ le reconoce la personería jurídica de derecho público, que le es propia".

Pienso que una norma que garantice a la Iglesia su autonomía adintra respecto de las posibles intervenciones del Estado es necesaria, te-

10 Acordo entre a República Federativa do Brasil e a Santa Sé relativo ao estatuto jurídico da Igreja católica no Brasil (2008), art. 2: "A República Federativa do Brasil, com fundamento no direito de liberdade religiosa, reconoce à Igreja Católica o direito de desempenhar a sua missao apostólica, garantindo o exercício público de suas atividades, observando o ordenamento jurídico brasileiro". Su texto en Martín de Agar, José T. (2010) I concordati dal 2000 al 2009. Città del Vaticano: Libreria Editrice Vaticana, 317 pp., p. 42. 
niendo en cuenta, por lo demás, que es el propio derecho chileno el que la garantiza, pero la desvincularía de la personalidad jurídica de la Iglesia que amerita un tratamiento específico. Sobre esta base, pienso que el artículo primero de un futuro concordato debería llevar dos incisos, de manera que, en el primero, se garantice la libertad de la Iglesia ad-extra y en el segundo ad-intra, artículo que concebiría en los siguientes términos:

"\$1. La República de Chile, sobre la base del derecho de libertad religiosa, reconoce a la Iglesia católica el derecho de desarrollar con plena autonomia su misión apostólica, garantizando el ejercicio público de sus actividades, en conformidad con el ordenamiento jurídico chileno.

$\$ 2$. La República de Chile asegura a la Iglesia católica y a los organismos que la integran o que de ella dependen según el derecho canónico, el libre ejercicio de su poder espiritual y de su jurisdicción eclesiástica".

\section{2) Personalidad JURídica}

Según se ha podido advertir, ninguno de los dos primeros artículos de los proyectos gubernamentales se referían a la personalidad jurídica de la Iglesia, silencio que es suplido por el artículo 2 del proyecto del nuncio. En efecto, en ninguna parte del articulado de los dos proyectos presentados por el gobierno se hacía referencia a que la Iglesia o alguna de sus entidades tuviese personalidad jurídica, no obstante que el concordato con Lituania, que el gobierno tuvo a la vista para la redacción de los mismos, habla expresamente de "personas jurídicas eclesiásticas y religiosas"11. Tal omisión no es de extrañar porque era uno de los temas discutidos en ese momento, una vez producida la separación IglesiaEstado, pues había quienes entendían que, producida dicha separación, la Iglesia había perdido la calidad de persona jurídica de derecho público pasando a ser solo persona jurídica de derecho privado ${ }^{12}$.

La tesis que finalmente se impuso fue que la nueva Constitución no había alterado la situación anterior, de manera que las "iglesias", las "comunidades religiosas”, expresiones ambas utilizadas por el Código Civil (art. 547 inc. $2^{\circ}$ ), y la misma Iglesia católica conservaban su calidad de personas jurídicas de derecho público, lo que fue reconocido tanto por la jurisprudencia judicial como administrativa ${ }^{13}$. En todo caso, así lo habían

11 Por ejemplo, artículos XVI, XVII, XXII. Su texto en Enchiridion dei concordati. Due secoli dei rapporti Chiesa-Stato (2003). Bologna: Dehoniane, 2257 pp., pp. 698-711, No 13861421.

12 Alessandri Rodríguez, Arturo; Somarriva Undurraga, Manuel (1962) Curso de derecho civil. Redactado y puesto al día por Antonio Vodanovic. Santiago: tomo I, vol. 2, 397 pp., pp. 278-285.

13 Salinas (2004) 263-279. 
entendido los obispos de Chile quienes, en la pastoral colectiva que escribieron sobre la separación de la Iglesia y el Estado ${ }^{14}$, expresaban que " $p a-$ sando a lo temporal, la nueva Constitución no innova en el reconocimiento ni en la organización de la personalidad juridica de que gozaba la Iglesia bajo el imperio de la Constitución de 1833 y de las leyes existentes en el momento de su reforma". Es por lo que, años después, los constituyentes de 1980 dejaron constancia que, tratándose del reconocimiento de la personalidad jurídica de derecho público de la Iglesia católica, "este reconocimiento ha sido hecho por el propio constituyente de 1925"15.

Este reconocimiento fue nuevamente reiterado en 1999, cuando el artículo 20 de la ley 19.638, que estableció el procedimiento para que las entidades religiosas diversas de la Iglesia católica alcanzaren personalidad jurídica de derecho público, dispuso que "el Estado reconoce el ordenamiento, la personalidad jurídica, sea ésta de derecho público o de derecho privado, y la plena capacidad de goce y ejercicio de las iglesias, confesiones e instituciones religiosas que los tengan a la fecha de publicación de esta ley [14 de octubre de 1999], entidades que mantendrán el régimen juridico que les es propio...". Era la primera vez que un texto legal posterior a la Constitución de 1925 reconocía la personalidad jurídica de derecho público de la Iglesia. Más aún, al aprobarse esta ley en el Senado, "para evitar cualquier tipo de discusión que se podría suscitar el dia de mañana acerca del sentido y alcance del artículo 20", se dejó constancia que de acuerdo con dicho artículo 20 "la Iglesia católica y, luego, la Iglesia católica apostólica ortodoxa de Chile han sido reconocidas por nuestro ordenamiento jurídico como personas juridicas de derecho público" 16.

No obstante lo anterior, la Iglesia católica actúa habitualmente a través de un sistema organizativo conformado por una pluralidad de entes que son los que, de hecho, intervienen en el tráfico jurídico. Dos de ellos son genéricamente enunciados en el Código Civil cuando, al marginar de las normas sobre personas jurídicas de derecho privado a las corporaciones y fundaciones de derecho público, enuncia a las "iglesias" y a las "comunidades religiosas". Con la primera de dichas expresiones se entienden las diversas circunscripciones integrantes de la organización jurisdiccional de la Iglesia a las que el mismo derecho canónico otorga personalidad jurídica, a saber, conforme al Código de Derecho Canónico

\footnotetext{
14 Obispos de Chile (1925) "Pastoral colectiva de los obispos de Chile, sobre la reparación de la Iglesia y el Estado”. La Revista Católica. Año 25 No 578, pp. 488-491, p. 490.

$15 \quad$ El texto continúa así: "especialmente en la disposición transitoria de la Carta que autorizó al Estado para entregar al arzobispo de Santiago durante cinco años cierta suma de dinero para invertirla en el país en las necesidades del culto de la Iglesia católica, como del artículo $72 n^{\circ} 16$, que señalaba entre las atribuciones especiales del presidente de la República la de celebrar concordatos", en Actas oficiales de la Comisión Constituyente (1975) “Acta de la sesión 132, de 23 de junio de 1975 ”, pp. 2 y 12.

16 Diario de sesiones del Senado (1999) sesión 10a en martes 6 de julio, pp. 1097-1098.
} 
vigente, las iglesias particulares, en las cuales y desde las cuales existe la Iglesia católica una y única, esto es, principalmente las diócesis, territoriales o personales (can. 368, 372, 373), las circunscripciones asimiladas a ellas, es decir, la prelatura territorial, la abadía territorial, el vicariato apostólico, la prefectura apostólica y la administración apostólica erigida de manera estable (can. 368, 373) y las parroquias territoriales o personales (can. $515 \$ 3,518)$. Con la segunda de las expresiones utilizadas por el Código Civil, esto es, las "comunidades religiosas", hay que entender lo que el Código de Derecho Canónico vigente denomina Institutos de vida consagrada (can. 573-709), entre los que hay que comprender a los institutos seculares (can. 710-730), y las sociedades de vida apostólica (can. 731-746).

Además de las anteriores, existen en la Iglesia otras entidades que responde al fenómeno asociativo de los fieles y que encauzan el actuar de los mismos en el seguimiento más cercano de Cristo y la vivencia más intensa de su vida de fe. Estas agrupaciones, como las cofradías, no fueron desconocidas al Código Civil ${ }^{17}$, pero no las enunció entre las personas jurídicas de derecho público, lo que originó que el arzobispo de Santiago junto a los obispos de La Serena y Concepción, representaran al Senado ${ }^{18}$ el temor de que algunos quisieran aplicarles a ellas las reglas que el Código Civil fija para las personas jurídicas de derecho privado. A decir verdad, el Código Civil nunca quiso incluirlas entre las personas jurídicas de derecho público y así lo comprendió finalmente la Iglesia católica cuando en el decreto 78 del Concilio Plenario de Chile (1946), dispuso que "las personas juridicas de derecho privado eclesiástico, como son las asociaciones de fieles, $v$. gr. cofradias u otras que no forman parte de la organización constitutiva de la Iglesia, para que alcancen a ser reconocidas por el derecho civil, en la condición de personas jurídicas, es necesario que se sometan al trámite establecido por la ley chilena a fin de obtener la ley o el decreto correspondientes que aprueba sus estatutos y las constituye en personas juridicas".

Mientras estuvo vigente el Código de Derecho Canónico de 1917, personalidad jurídica canónica solo tuvieron las entidades eclesiales que coincidían con las expresiones "iglesias" y "comunidades religiosas" utilizadas por el Código Civil, no así aquellas otras que no formaban parte "de la organización constitutiva de la Iglesia" y que, en general, respon-

17 P. ej. artículos 965 inc. $1^{\circ}$, que declara incapaz de recibir herencia o legado por testamento otorgado durante la última enfermedad, a la cofradía de que es miembro el último confesor del causante; o el art. 963, que establece la incapacidad de toda herencia o legado de las cofradías que no son personas jurídicas.

18 "Representación que hacen a la H. Cámara de Senadores [en 1857] el Ilmo. y Rmo. Señor Arzobispo de la Metrópoli de Santiago de Chile, Dr. D. Rafael Valentín Valdivieso, e Ilustrísimos señores obispos sufragáneos de La Serena y Concepción (1902). En Astorga, José Ramón (recop.), Obras cientificas i literarias del Ilmo. y Rmo. Sr. Don Rafael Valentín Valdivieso, arzobispo de Santiago de Chile. Santiago de Chile, vol. II, 983 pp., pp. 27-58. 
dían al afán asociativo de los fieles. Cualquier concordato, en consecuencia, que hubiese querido reconocer personalidad jurídica de derecho público a entidades eclesiales conforme a las normas nacionales, solo podía reconocerla a las "iglesias" y "comunidades religiosas" que eran las únicas que tenían personalidad jurídica canónica. Sin embargo, un nuevo elemento fue incorporado al entrar en vigencia el Código de Derecho Canónico de 1983.

En efecto, el código canónico actual introdujo en el derecho de la Iglesia la distinción entre personas jurídicas públicas y privadas. "Son personas jurídicas públicas las corporaciones y fundaciones constituidas por la autoridad eclesiástica competente para que, dentro de los límites que se les señalan, cumplan en nombre de la Iglesia, a tenor de las prescripciones del derecho, la misión que se les confía mirando al bien público; las demás personas jurídicas son privadas" (can. $116 \$ 1$ ). Las personas jurídicas públicas adquieren esta personalidad, bien en virtud del mismo derecho ${ }^{19}$, bien por decreto especial de la autoridad competente que se la concede expresamente; las personas jurídicas privadas la obtienen solo mediante decreto especial de la autoridad competente que se las concede expresamente (can. $116 \$ 2$ ). Por lo general, conforme al nuevo código canónico tienen personalidad jurídica canónica pública las entidades eclesiales que en el Código Civil son identificadas como "iglesias" y "comunidades religiosas", con lo que, al menos desde esta perspectiva, no se ha producido ninguna novedad. Pero, además, la competente autoridad eclesiástica puede otorgar la calidad de persona jurídica canónica pública a entidades eclesiales que responden al fenómeno asociativo general de la iglesia y que el nuevo Codex enuncia con la expresión general de "asociaciones de fieles", las que pueden ser asociaciones públicas (can. 312-320) o privadas (can. 321-326); las públicas quedan constituidas en persona jurídica en virtud del mismo decreto por el que las erige la autoridad eclesiástica competente (can. 313); las privadas pueden o no tener personalidad jurídica (can. 322).

A la luz de esta innovación surge de inmediato la pregunta: estas entidades eclesiales diversas a las "iglesias" y a las "comunidades religiosas", pero que tienen personalidad jurídica canónica, pública o privada, ¿tienen, de cara al derecho chileno, personalidad jurídica? La respuesta afirmativa no ofrece dudas, pues el artículo 9 de la ley 19.638 dispone que las "asociaciones, corporaciones, fundaciones y otros organismos creados por una iglesia, confesión o institución religiosa, que conforme a sus normas jurídicas propias gocen de personalidad jurídica religiosa, son reconocidos como tales. Acreditará su existencia la autoridad religiosa que los haya erigido o instituido". Pero, ¿qué personalidad jurídica tendrán conforme al derecho

19 P. ej. los seminarios (can. $238 \$ 1$ ), las iglesias particulares (can. 373), la provincia eclesiástica $($ can. $432 \$ 2)$, las conferencias episcopales (can. $449 \$ 2)$, la parroquia (can. $515 \$ 3$ ). 
chileno? ¿Personalidad jurídica de derecho público o de derecho privado? Si tienen personalidad jurídica canónica privada, parece que la respuesta no ofrece mayores dudas: serán personas jurídicas de derecho privado. Pero ¿si tienen personalidad jurídica canónica pública? En otro lugar ${ }^{20}$ he afirmado que tanto las personas jurídicas canónicas privadas y públicas que no puedan reconducirse a las expresiones "iglesias" y "comunidades religiosas" que emplea del Código Civil, han de ser personas jurídicas de derecho privado en el ordenamiento jurídico chileno. La limitación que me imponen estas páginas me impide extenderme en este punto por lo que me remito a dichas páginas.

Pienso que un concordato entre la Santa Sede y el Estado de Chile no ha de buscar privilegios para la Iglesia católica sino que, en el marco del derecho de libertad religiosa garantizado constitucional y legalmente, es conveniente tan solo recoger por escrito la situación actualmente existente en los temas que interesan a ambos. Parece, así, conveniente que en un acuerdo entre ellos se reconozca la personalidad jurídica de derecho público de la Iglesia conforme al derecho actualmente vigente en Chile, según el cual dicha personalidad se reconoce a las "iglesias" y "comunidades religiosas", conceptos ambos empleados por el Código Civil, que la doctrina y jurisprudencia se han encargado de precisar. Es, por lo demás, el régimen que ha tenido la Iglesia bajo la vigencia de las últimas dos Constituciones. Las demás entidades eclesiales que tengan personalidad jurídica canónica, sea pública o privada, tienen reconocida dicha personalidad por la ley 19.638, y ella será de derecho privado.

A la luz de lo anterior, pienso que una propuesta de artículo podría ser la siguiente:

"\$1. El Estado de Chile reconoce la personalidad jurídica de derecho público de la Iglesia católica, de la Conferencia Episcopal de Chile, de las personas jurídicas canónicas que forman parte de su estructura jerárquica, de las prelaturas personales, de los Institutos de Vida Consagrada y de las Sociedades de Vida Apostólica.

$\$$ 2. El Estado de Chile reconoce la personalidad jurídica de derecho privado de las demás entidades eclesiales que obtengan personalidad juridica conforme al derecho canónico, lo que será acreditado mediante certificación de la autoridad competente que la haya conferido".

\section{3) RÉGIMEN PATRIMONIAL}

Supuesta la personalidad jurídica, corresponde reconocer la capacidad patrimonial de la Iglesia y de las entidades eclesiales. El Código de

20 SALINAS (2004)274-279. 
Derecho Canónico afirma en forma solemne que "por derecho nativo, $e$ independiente de la potestad civil, la Iglesia católica puede adquirir, retener, administrar y enajenar bienes temporales para alcanzar sus fines propios" (can. 1254 \$2). Conforme a ello, "la Iglesia universal y la Sede Apostólica, y también las iglesias particulares y cualquier otra persona jurídica, tanto pública como privada, son sujetos capaces de adquirir, retener, administrar y enajenar bienes temporales, según la norma jurídica" (can. 1255).

Se refería a esta materia el artículo 20 del Proyecto I que, sin modificaciones, pasó a ser el artículo 18 del Proyecto II, según los cuales "Conforme a la legislación chilena, las iglesias, los ordinarios, las parroquias y las comunidades religiosas legalmente establecidas en Chile estarán facultadas para adquirir, poseer, ceder y administrar, ciñéndose a las reglas del derecho canónico, sus bienes muebles e inmuebles, como también para comparecer ante las autoridades del Estado en resguardo de sus derechos civiles". El Proyecto III, daba a esta materia una nueva ubicación, pues pasaba a ser el artículo 3, y una nueva redacción, recogiendo, por un lado, aquella parte del artículo 2 de los dos proyectos gubernamentales en los que se aseguraba a la Iglesia y a los organismos que dependían de ella, la libre administración de sus bienes y negocios conforme al derecho canónico y a las leyes chilenas; y, por otra, el artículo 20 del Proyecto I que pasó a ser el artículo 18 del Proyecto II, de manera que el texto del Proyecto III quedó así: "Todas las personas jurídicas eclesiásticas y religiosas, reconocidas como tales por el derecho canónico, gozarán, por consiguiente, de plena libertad para adquirir, a título oneroso o gratuito, toda clase de bienes, muebles o inmuebles, para poseerlos, administrarlos, gravarlos o enajenarlos, conforme al derecho canónico y a las leyes actualmente en vigor para las personas juridicas de derecho público, como también para comparecer ante las autoridades del Estado en resguardo de sus derechos civiles". El proyecto del nuncio le daba autonomía a esta libertad, la que conectaba con la personalidad jurídica de derecho público, interesado como estaba, de que esta quedara firmemente asentada. Esta "plena libertad" es una consecuencia - "por consiguiente" - de dicha personalidad jurídica de derecho público, y disfrutaban de ella "todas las personas eclesiásticas y religiosas reconocidas como tales por el derecho canónico", esto es, las que el Código Civil denominaba "iglesias" y "comunidades religiosas". El texto del artículo las dejaba bien resguardadas y quedaban superadas las dudas del diplomático vaticano.

A la luz de lo anterior y tomando en cuenta que lo propuesto por estos proyecto es lo que ha venido sucediendo de hecho en Chile ininterrumpidamente, pienso que un acuerdo con la Santa Sede podría incluir una norma similar. Por lo demás, el derecho de la Iglesia católica a ser titular de un patrimonio propio está reconocido por nuestra legislación interna cuando la ley 19.638 de entidades religiosas dispone que "el Estado reconoce el ordenamiento, la personalidad jurídica, sea ésta de derecho público o de derecho privado, y la plena capacidad de goce y ejercicio de las iglesias, 
confesiones $e$ instituciones religiosas que los tengan a la fecha de publicación de esta ley [14 de octubre de 1999], entidades que mantendrán el régimen jurídico que les es propio" (art. 20). Más aún, el Estado de Chile ha venido a "civilizar", esto es, ha hecho civiles, las normas canónicas patrimoniales, al establecer que "las normas jurídicas propias de cada una de ellas forman parte de los requisitos de validez para la adquisición, enajenación y administración de sus bienes" (art. 14); si bien esto está establecido para "las personas jurídicas constituidas conforme a esta ley", también es cierto que no puede haber "trato desigual" entre las antiguas y las nuevas entidades religiosas (art. 20).

Por otra parte, teniendo presente que según la misma ley "las entidades religiosas podrán solicitar y recibir toda clase de donaciones y contribuciones voluntarias... y organizar colectas entre sus fieles, para el culto, la sustentación de sus ministros u otros fines propios a su misión" (art. 15), me parece pertinente agregar un inciso en que dicho derecho fuere expresamente reconocido a la Iglesia católica. De esta manera la redacción podría ser la siguiente:

"\$ 1. El Estado de Chile reconoce a la Iglesia universal y la Sede Apostólica, a las iglesias particulares y cualquier otra persona juridica, tanto pública como privada, erigidas conforme al derecho canónico, su calidad de sujetos capaces de adquirir, retener, administrar y enajenar bienes temporales, según el derecho canónica y el derecho de la República de Chile.

"\$2. El Estado reconoce el derecho de la Iglesia católica a recabar libremente de los fieles contribuciones y ofrendas para sostener el culto divino, sustentar honestamente al clero y demás ministros y hacer las obras de apostolado y caridad, sobre todo con los más necesitados".

\section{4) RÉGIMEN TRIBUTARIO}

Una vez afirmado el derecho de la Iglesia a poseer bienes, procede fijar el régimen tributario que corresponde respecto de dicho patrimonio. Es lo que hacía el artículo 3 del Proyecto I que, con el mismo texto y número, pasó al Proyecto $\mathrm{II}^{21}$. El proyecto del nuncio, redactado en tres incisos, distinguía en los dos primeros incisos del artículo 4 la regla general

21 Proyecto I, art. 3; Proyecto II, art. 3: "Los eclesiásticos, sus bienes y los de las iglesias, ordinarios, parroquias y comunidades religiosas quedan sometidos a impuestos del mismo modo que las personas y los bienes de los ciudadanos de la República y que las personas jurídicas laicas, pero estarán exentos de contribuciones los templos y sus dependencias, destinados al servicio del culto católico, las casas parroquiales y de residencia de los ordinarios, los hospitales, hospicios, orfelinatos y, en general, los locales de instituciones católicas destinadas a dar auxilio o habitación gratuita a los desvalidos, en la parte afecta a tales servicios y siempre que ninguna porción de su renta sea destinada a fines de lucro personal, y los locales de los seminarios, universidades, escuelas y colegios católicos en las partes afectas a servicios de instrucción y que no produzcan rentas". 
de tributación de los bienes eclesiásticos y las exenciones, añadiendo, en un tercer inciso, situaciones que los otros proyectos no contemplaban ${ }^{22}$.

En lo que se refiere al pago de impuestos por las personas eclesiales, es menester tener presente que ello ocurre en forma generalizada sin que el hecho de ser persona eclesiástica sea motivo para que haya diferenciaciones con el resto de las personas naturales o jurídicas. Pero, la legislación común ha ido estableciendo exenciones respecto de los diversos tributos hoy existentes en el país, exenciones que, en ocasiones, están establecidas en atención a la calidad religiosa del contribuyente, pero que en otras ocasiones benefician a esos contribuyentes no por su calidad religiosa, sino por la actividad que desarrollan; y en el primer caso, el beneficio es a favor de cualquier persona religiosa, no necesariamente católica $^{23}$. Entre las primeras, por ejemplo, están exentas del impuesto de timbres y estampillas las "instituciones con personalidad jurídica cuyo fin sea el culto"24; y están exentas del impuesto a las asignaciones y donaciones "las asignaciones o donaciones que se dejan para la construcción o reparación de templos destinados al servicio de un culto o para el mantenimiento del mismo culto" 25 . Entre las segundas, por ejemplo, están exentas del mismo impuesto, "las donaciones y asignaciones cuyo único fin sea la beneficencia, la difusión de la instrucción o el adelanto de la ciencia en el pais" 26 . Y en lo que se refiere al impuesto a la renta, supuesto que, conforme al derecho canónico "la Iglesia tiene el derecho nativo de exigir de los fieles los bienes que necesita para sus propios fines" 27 , y conforme a la ley de entidades religiosas, "las entidades religiosas podrán solicitar y recibir toda clase se donaciones y contribuciones voluntarias de particulares e instituciones públicas o

22 Proyecto III, art. 4: "[inc. $1^{\circ}$ ] Los eclesiásticos, sus bienes y los de las personas jurídicas eclesiásticas y religiosas (obispados, cabildos, parroquias, comunidades religiosas, seminarios, etc.) quedan sometidos a impuestos del mismo modo que las personas y los bienes de los ciudadanos de la República y que las personas jurídicas laicas de derecho público. [inc. 2o] Estarán, sin embargo, exentos de contribuciones los templos y sus dependencias, dedicados al servicio del culto católico; las residencias episcopales y parroquiales con sus dependencias; los conventos, hospitales, hospicios, orfelinatos, y en general, los locales de instituciones católicas destinadas a dar auxilio o habitación gratuita a los desvalidos, en la parte afecta a tales servicios; los seminarios, las universidades, las escuelas y colegios católicos. [inc. 3] Quedarán también exentos de pago de contribuciones los bienes destinados al mantenimiento de las instituciones de beneficencia y de instrucción expresados en el inciso anterior".

23 El tema lo analizo latamente en SaLinas (2004) 329-380.

24 Decreto ley No 3.475 , art. 23 no 9.

25 Ley No 16.271, art. 18 no 4. En una circular reciente del Servicio de Impuestos Internos se ha aclarado que, para los efectos de estas donaciones, "la palabra culto debe entenderse como un conjunto de ritos y ceremonias litúrgicas con que se tributa religiosamente a lo que se considera divino o sagrado". Circular no 45 de 24 de septiembre de 2012.

26 Ley No 16.271, art. 18 n 5 .

27 Código de Derecho Canónico (1983), can. 1260. Por su parte el can. $222 \$ 1$, dispone que "los fieles tienen el deber de ayudar a la Iglesia en sus necesidades, de modo que disponga de lo necesario para el culto divino, las obras de apostolado y de caridad y el conveniente sustento de los ministros". 
privadas y organizar colectas entre sus fieles, para el culto, la sustentación de sus ministros $u$ otros fines propios de su misión" 28 , las donaciones o erogaciones voluntarias de los fieles - "colectas" en palabras de la ley- no constituyen renta por disposición de la ley de impuesto a la renta ${ }^{29}$.

En lo referido a la exención del impuesto territorial, la Constitución dispone que "los templos y sus dependencias, destinados exclusivamente al servicio de un culto, estarán exentos de toda clase de contribuciones" (art. 19 $\mathrm{n}^{\circ} 6$ inc. $3^{\circ}$ ). En lo que se refiere al impuesto territorial, la ley $17.235^{30}$ exime del 100\% "los templos y sus dependencias destinados al servicio de un culto como asimismo las habitaciones anexas a dichos templos ocupadas por los funcionarios del culto y siempre que no produzcan rentas" 31 . En cambio, los conventos, mencionados por el proyecto del nuncio, pero en ninguno de los proyectos gubernamentales de concordato, quedaron excluidos de la exención ${ }^{32}$.

A las exenciones anteriores hay que agregar otras establecidas, en general, en beneficio de determinados bienes inmuebles, en atención a la función que en ellos se desarrolla, independiente de quien sea su propietario, los cuales quedan exentos del impuesto territorial, pero no por ser religiosos o de una entidad religiosa. Cuando ellos son de propiedad de la Iglesia católica o de alguna persona jurídica canónica, gozan de la exención: cementerios ${ }^{33}$; establecimientos educacionales particulares y particulares subvencionados, de educación prebásica, básica y media, reconocidos por el Ministerio de Educación, y los seminarios asociados a un culto religioso, todos ellos, en la parte destinada exclusivamente a la educación ${ }^{34}$; universidades, institutos profesionales y centros de formación técnica reconocidos por el Ministerio de Educación, de carácter privado, respecto de los bienes raíces de su propiedad destinados a educación, investigación y extensión, y siempre que no produzcan renta por actividades destinadas a dichos objetos ${ }^{35}$; los establecimientos destinados

Decreto Ley No 824, art. 17 no 9 y 11 . Véase el Oficio no 313 de 22 de enero de 2001 de la subdirección normativa del departamento de impuestos directos del Servicio de Impuestos Internos, en La Semana Jurídica (27 agosto-2 septiembre 2001) que responde a una consulta hecha a propósito por un pastor evangélico.

30 Decreto No 2.106, de hacienda, publicado en Diario Oficial de 16 de enero de 1975, actualmente vigente.

31 Cuadro Anexo [= CA.] I, B, 5.

32 "El señor Guerra (don J. Guillermo) pregunta: ¿y un convento? S[u] E[xcelencia] contesta: paga contribuciones". Actas oficiales (1975) 317.

33 CA. I, B, 4. Los cementerios de propiedad particular, como los cementerios parroquiales, están afectos al impuesto territorial solo por las edificaciones destinadas a la administración de la actividad, y por los terrenos disponibles para sepulturas y equipamiento anexo, que no se encuentren habilitados para ello.

CA. I, B, 1 .

CA. I, B, 2 . 
a proporcionar auxilio o habitación gratuita a los indigentes y desvalidos ${ }^{36}$; los edificios de las misiones diplomáticas, cuando pertenezcan al gobierno respectivo, caso en el que se encuentra la sede de la nunciatura en Chile ${ }^{37}$; los monumentos declarados históricos o públicos ${ }^{38}$. A lo anterior, hay que agregar algunas exenciones del impuesto territorial que benefician a instituciones determinadas, pertenecientes a la Iglesia católica, como el Hogar de Cristo, que goza de la exención del 75\% ${ }^{39}$ del tributo.

Teniendo presente lo antes expuesto, la materia merece estar incorporada en un acuerdo con Roma con un artículo cuyo tenor puede ser el siguiente:

"\$1. Las personas naturales y juridicas regidas por el derecho canónico quedan sometidas a impuestos del mismo modo que las personas y los bienes de los ciudadanos de la República y que las personas jurídicas.

"\$ 2. Los templos y sus dependencias dedicados exclusivamente al servicio del culto de la Iglesia católica estarán exentos de contribuciones. Los demás edificios y dependencias de propiedad de personas juridicas erigidas conforme al derecho canónico, quedarán exentos de contribuciones conforme al derecho común.

"\$3. La Iglesia católica y las personas juridicas regidas por el derecho canónico tendrán los mismos derechos, exenciones y beneficios tributarios que la Constitución Politica de la República, las leyes y reglamentos vigentes otorguen y reconozcan a otras iglesias, confesiones e instituciones religiosas existentes en el pais".

\title{
5) LIBRE COMUNICACIÓN CON ROMA
}

Según el artículo 4 del Proyecto I, "los obispos y el clero podrán comunicarse libre y directamente con la Santa Sede, y en la misma forma podrán los obispos comunicarse con el clero y fieles de su dependencia y publicar sus pastorales y ordenanzas", artículo que pasó en los mismos términos a ser el artículo 4 del Proyecto II, el que agregó una frase final según la cual lo dispuesto en dicha norma era "siempre que no contrarien las leyes chilenas". El Proyecto III retomó la redacción del Proyecto I, eliminando el añadido del Proyecto II.

Este artículo recoge algo que ha sido la práctica cotidiana en Chile a partir de 1925 por lo que su inclusión en un acuerdo no ofrece dificultad. Sin embargo, la fórmula empleada por el proyecto del nuncio garantizaba la libre comunicación desde Chile hacia Roma, pero guardaba silencio en

\author{
CA. I, D, 3. \\ CA. I, B, 7. \\ CA. I, B, 12 \\ CA. II, A, 1 .
}


lo que se refería a la comunicación de Roma con Chile, a pesar de que tampoco ha habido en esta materia dificultad alguna. Es por lo que, en mi opinión, un futuro acuerdo, podría garantizar la comunicación con y desde Roma, además de la libertad de los obispos para comunicarse con sus fieles. Mi propuesta es la siguiente:

"\$1. La Santa Sede puede comunicarse libremente con los obispos, el clero y los fieles, asi como estos pueden hacerlo con la Santa Sede.

“\$2. Los obispos y las otras autoridades eclesiásticas gozan de la misma libertad en relación con el clero y los fieles, con las Conferencias episcopales de otros paises, y también con iglesias particulares, instituciones y personas tanto dentro como fuera del territorio de la República".

\section{6) RESGUARDO DEL ORDEN EN ACTOS PÚBLICOS}

El artículo 5 del Proyecto $\mathrm{I}^{40}$ que, con leves cambios de redacción, se repitió en los otros dos proyectos, recogía un resabio anacrónico del viejo apoyo del brazo secular a la Iglesia, lo que, claramente, no tiene cabida en un futuro acuerdo. Sin embargo, en la segunda parte de este artículo se aseguraba el resguardo del orden en actos o manifestaciones religiosas en lugares públicos y en las otras circunstancias en que tal apoyo estuviere prescrito o permitido por las leyes chilenas. Se trata de una materia diversa, pues entra en la obligación que corresponde al Estado de velar por el orden en los actos que se desarrollan en los lugares públicos, cualquiera sea la naturaleza de los mismos.

En lo que se refiere a los actos propiamente religiosos, la ley 19.638 de entidades religiosas garantiza a toda persona el derecho de profesar la creencia religiosa que libremente elija (art. 6 a), pudiendo practicar en público o en privado, individual o colectivamente, actos de oración o de culto (art. $6 \mathrm{~b}$ ) y reunirse o manifestarse públicamente con fines religiosos (art. 6 e). Siendo un derecho reconocido por la ley chilena, cuyo ejercicio en lugares públicos está debidamente protegido por el ordenamiento jurídico chileno, no parece exagerado incluirlo en un acuerdo con la Santa Sede si el criterio que rige su contenido es incorporar todo aquello que ya sucede al amparo del ordenamiento jurídico chileno. En esta perspectiva, recogiendo parte del artículo propuesto por el gobierno en 1928 y respetado por el nuncio, me parece que el texto de este artículo podría ser el siguiente: "Las autoridades chilenas asegurarán el resguardo del orden en actos

40 Proyecto I, art. 5; Proyecto II, Art. 5; Proyecto III, art. 6: "Las autoridades chilenas apoyarán la ejecución de las decisiones y de los decretos eclesiásticos en casos de prohibición a un eclesiástico del ejercicio del ministerio sacerdotal en locales públicos destinados al culto o del uso del hábito eclesiástico, de resguardo del orden en actos o manifestaciones religiosas en lugares públicos y en las otras circunstancias en que prescriban o permitan tal apoyo las leyes chilenas". 
o manifestaciones religiosas en lugares públicos y en las otras circunstancias en que prescriban o permitan tal apoyo las leyes chilenas".

\section{7) EXENCIONES DE LOS CLÉRIGOS}

\section{1) SERVICIO MILITAR}

El artículo 8 del Proyecto ${ }^{41}$ que, con un leve cambio, pasó con el mismo número al Proyecto II, reguló, en un inciso único, el servicio militar de los clérigos, materia que el nuncio, en un artículo con la misma numeración ${ }^{42}$, distribuyó en dos incisos, incorporó un tercer inciso nuevo y agregó, en un inciso $4^{\circ}$, lo que en el Proyecto I estaba regulado en el artículo $9^{43}$.

En lo referido al servicio militar, el Código de Derecho Canónico de 1983 dispone que "dado que el servicio militar es menos congruente con el estado clerical, los clérigos y asimismo los candidatos a las órdenes sagradas no se presenten voluntariamente al servicio militar, si no es con licencia de su Ordinario" (can. $289 \$ 1$ ) norma que vale también para los religiosos (can. 672). Y el decreto ley 2.306, que dicta normas sobre reclutamiento y movilización de las Fuerzas Armadas ${ }^{44}$, modificado el año 2005 para adecuarlo a la ley de entidades religiosas de 1999, establece que "estarán exentos del deber militar, mientras permanezcan en sus cargos: 7. Los ministros de culto pertenecientes a iglesias, confesiones e instituciones religiosas que gocen de personalidad jurídica de derecho público, siempre que acrediten su calidad de tales mediante certificación expedida por sus respectivas entidades religiosas" (art. 17).

$41 \quad$ Proyecto I, art. 8: "Los eclesiásticos que ya hubieren sido ordenados, los religiosos que ya hubieren hecho votos, los alumnos de los seminarios y los novicios que bubieren ingresado a los seminarios o noviciados antes de una declaración de guerra, estarán exentos del servicio militar obligatorio, exceptuando el caso de reclutamiento general. En este último caso y cuando se enrolaren voluntariamente, los miembros del clero y religioso, especialmente los sacerdotes ordenados, serán destinados de preferencia a ejercer su ministerio en las filas o a los servicios sanitarios o de administración”.

42 Proyecto III, art. 8: "[inc. 10] Los sacerdotes seculares y regulares, los religiosos profesos, los alumnos de la sección eclesiástica de los seminarios y los de los noviciados estarán exentos del servicio militar obligatorio, exceptuando el caso de reclutamiento general. [inc. $2^{\circ}$ ] En este caso, y cuando se enrolaren voluntariamente, serán llamados a ejercer su ministerio en las filas o destinados a los servicios sanitarios o de administración. [inc. $3^{\circ}$ ] Aún en caso de reclutamiento general, quedarán exentos del servicio militar los párrocos, los sacerdotes seculares y regulares en cura de almas o en servicio de iglesias, y el personal eclesiástico indispensable para el funcionamiento de las curias diocesanas, de los seminarios, y de los colegios católicos. [inc. 40] Los eclesiásticos estarán también exentos de cualquiera obligación de ejercer funciones o cargos civiles incompatibles con la vocación sacerdotal, en conformidad con el derecho canónico".

43 Proyecto I, art. 9: "Los eclesiásticos estarán exentos de ejercer funciones o encargos incompatibles con el ministerio sacerdotal, como el de administrar justicia en asuntos ajenos al fuero eclesiástico".

$44 \quad$ Publicado en Diario Oficial de 12 de septiembre de 1978. 
Puesto que la exención del servicio militar de los ministros de culto es una norma vigente en Chile, parece adecuado incorporarla a un futuro acuerdo; es claro que la ratio legis no se encuentra en tratarse de un derecho inherente a la persona de los ministros de culto, católicos o no, sino que hay que encontrarla en la necesidad de preservar un servicio social a los ciudadanos, servicio que se vería menoscabado al extraerlos de las comunidades en las que brindan sus servicios religiosos. Ahora bien, la norma vigente en Chile se refiere expresamente a "los ministros de culto pertenecientes a iglesias, confesiones e instituciones religiosas que gocen de personalidad jurídica de derecho público". Si entendemos el concepto "ministro de culto" en su sentido natural, esto es, hombre o mujer consagrados especialmente a la divinidad para servir espiritualmente a la comunidad de fieles, no hay problema en comprender en el mismo a los religiosos, los que estaban expresamente mencionados en la redacción original de la norma, si bien ahora ha preferido unificarse la exención bajo una única expresión. Hemos, pues, de entender que en Chile están exentos del servicio militar no solo los sacerdotes católicos, sino también los religiosos, esto es, aquellos hombres y mujeres que, estando consagrados a Dios en una "institución religiosa" reconocida canónicamente, no han recibido el sacramento del orden, institución religiosa que, conforme al Código Civil, goza de personalidad jurídica de derecho público. Hay que tener presente que la ley, junto a las "iglesias" y "confesiones", incluye a las "instituciones religiosas".

La duda es qué pasa con quienes se preparan para dicha consagración, esto es, los seminaristas y los novicios. La existencia de los mismos no es desconocida por el derecho chileno pues la ley 19.638 de entidades religiosas le reconoce a las iglesias la posibilidad de fundar, mantener y dirigir en forma autónoma institutos de formación y de estudios teológicos o doctrinales (art. 8 a). Si el criterio para redactar un acuerdo con la Santa Sede es el de recoger el derecho chileno vigente, me parece que la respuesta a esta interrogante la proporciona el decreto ley 2.306 sobre reclutamiento y movilización de las Fuerzas Armadas que en su artículo 30 F establece una modalidad de ejecución del servicio militar para "los varones que se encontraren cursando el último año de enseñanza media, estudios tendientes a la obtención de un título profesional o técnico a nivel superior en establecimientos de educación superior del Estado o reconocidos por éste o realizando su práctica profesional' y que resultaren convocados para el servicio militar, los que, por una sola vez, pueden optar a las alternativas que ofrece la misma norma ${ }^{45}$, en cuyo caso los seminaristas y novicios podrían

45 En concreto: "1) conscripción ordinaria, en forma inmediata o al término de los estudios correspondientes. En ambos casos, podrán optar por la institución de las Fuerzas Armadas y la unidad que sean de su preferencia. 2) Prestación, hasta por ciento ochenta dias, de servicios vinculados a sus estudios en aquellas profesiones que interesen a las Fuerzas Armadas. 3) Participación, hasta por 
realizar su servicio militar adscritos a los servicios religiosos o de enfermería de los institutos armados.

¿Qué pasa en caso de reclutamiento general? La ley chilena no se refiere a esta materia, pero sí, como lo he señalado, la exención del servicio militar de los ministros de culto se explica en la necesidad de no suspender la atención religiosa y espiritual de los respectivos fieles, la misma ratio legis ha de iluminar la respuesta a esta pregunta, la que, en mi opinión, debería acoger la exención, al menos, para aquellos eclesiásticos con cura de almas.

Supuesto todo lo anterior, mi propuesta de artículo es la siguiente:

“ $\$ 1$. Los sacerdotes seculares y regulares y los religiosos profesos estarán exentos del servicio militar obligatorio.

"\$2. Los seminaristas o los novicios de institutos de vida consagrada o de sociedades de vida apostólica, haciendo uso de la modalidad alternativa de servicio militar acordada a los estudiantes, lo realizarán en el servicio religioso de cualquiera de las Fuerzas Armadas o de Orden y Seguridad".

"\$3. En caso de reclutamiento general, quedarán exentos del servicio militar los ordinarios, los párrocos, y los sacerdotes seculares y regulares con cura de almas. Los demás serán asignados al servicio religioso de las tropas o a los servicios de enfermería".

\section{2) CARgOS Y OFICIOS PÚBLICO AJENOS AL ESTADO CLERICAL}

Como lo adelanté, el artículo 9 del Proyecto $1^{46}$ establecía que los eclesiásticos estaban exentos de ejercer funciones o empleos incompatibles con el ministerio sacerdotal, norma que se recogía en los mismos términos en el artículo 8 de Proyecto II y que el nuncio, con nueva redacción, incorporó como inciso $4^{\circ} \mathrm{del}$ artículo 8 de su proyecto.

El Código de Derecho Canónico de 1983, después de disponer de manera general que los clérigos se abstengan "por completo de aquello que desdiga de su estado, según las prescripciones del derecho particular" (can. 285 \$ 1), establece que "les está prohibido a los clérigos aceptar aquellos cargos públicos que llevan consigo una participación en el ejercicio de la potestad civil' (can. $285 \$ 3$ ). Por su parte, el Código Orgánico de Tribunales dispone que no pueden ser jueces "los que hayan recibido órdenes eclesiásticas mayores" (art. $256 n^{\circ} 8$ ), razón por la cual el mismo código establece que el cargo de juez expira "por la recepción de órdenes eclesiásticas mayores" (art. 332 no 2); según el mismo cuerpo legal, "las funciones de los fiscales

ciento cincuenta días, en cursos especiales de instrucción militar para estudiantes del último año de enseñanza media o de establecimientos de educación superior del Estado o reconocidos por éste".

46 Proyecto I, art. 9: "Los eclesiásticos estarán exentos de ejercer funciones o encargos incompatibles con el ministerio sacerdotal, como el de administrar justicia en asuntos ajenos al fuero eclesiástico". 
judiciales son, además, incompatibles con las eclesiásticas y las de los defensores públicos con las eclesiásticas que tengan cura de almas" (art. 470).

Parece, pues, claro que nuestra legislación se hace eco de esta incompatibilidad, la que forma parte de nuestra legislación no solo porque se arrastra de ańos anteriores, sino que ella ha sido reiterada por reformas recientes, como que la incompatibilidad dispuesta para fiscales y defensores públicos fue establecida recién el año $2000^{47}$. De allí que, siguiendo el criterio de recoger en el concordato aquellas situaciones ya consolidadas en nuestro ordenamiento jurídico, la prohibición canónica dirigida a los clérigos de aceptar aquellos cargos públicos que llevan consigo una participación en el ejercicio de la potestad civil, que ya forma parte de nuestra legislación, debería figurar en el mismo. Pero no me parece que debiera estar incorporada en el artículo que regula la exención del servicio militar, sino en una norma aparte, tal como aparece sistemáticamente regulado en el Codex. Sugiero la siguiente redacción, de carácter general para no entrar en enunciación de situaciones específicas, redacción que sigue de cerca el texto propuesto por el nuncio: "Los eclesiásticos estarán exentos de ejercer funciones o cargos civiles incompatibles con la vocación sacerdotal, en conformidad con el derecho canónico".

\section{8) INMUNIDAD DE EDIFICIOS RELIGIOSOS}

El artículo 10 del Proyecto, recogido en los mismos términos como artículo 9 del Proyecto II ${ }^{48}$, aseguraba la inmunidad de iglesias, capillas, conventos y cementerios católicos, hasta donde lo permitiese el respeto de la ley chilena, condición, esta última, que fue eliminada del Proyecto III.

El derecho chileno contiene normas que garantizan a las confesiones religiosas, en un derecho establecido constitucionalmente, a "erigir y conservar templos y sus dependencias bajo las condiciones de seguridad e higiene fijadas por las leyes y ordenanzas" (art. 19 no 6 inc. 20), derecho constitucional que está definido legalmente en la ley de entidades religiosas, según la cual, las entidades religiosas tienen plena autonomía para "ejercer libremente su propio ministerio, practicar el culto, celebrar reuniones de carácter religioso y fundar y mantener lugares para esos fines" (art. 7 a).

Supuesto el derecho que la ley chilena otorga a la Iglesia católica de erigir "templos" o "lugares" para ejercer su propio ministerio y celebrar reuniones religiosas, el derecho canónico entiende por "iglesia... un edificio sagrado destinado al culto divino, al que los fieles tienen derecho a entrar

\footnotetext{
$47 \quad$ Ley No 19.665, art. 11.

48 Proyecto I, art. 10; Proyecto II, art. 9: "El Gobierno de Chile asegura la inmunidad de las iglesias, capillas, conventos y cementerios católicos hasta donde la permitan el respeto de la ley chilena y las exigencias de la seguridad pública".
} 
para la celebración, sobre todo pública, del culto divino" (can. 1214) el que, una vez concluida la construcción, "debe dedicarse o al menos bendecirse cuanto antes, según las leyes litúrgicas" (can. $1217 \$ 1$ ) lo que habilita para que puedan realizarse en él "todos los actos del culto divino" (can. 1219). El mismo código define lo que en la Iglesia se entiende por oratorio (can. 1223) y capilla privada (can. 1226), los cuales es conveniente que sean bendecidos y reservarse exclusivamente para el culto divino y quedar libres de cualquier uso doméstico (can. 1229); y también define los santuarios (can. 1230). Además, el Codex prescribe que "donde sea posible, la Iglesia debe tener cementerios propios" (can. $1240 \$ 1$ ), y las parroquias y los institutos religiosos "pueden tener cementerio propio" (can. $1241 \$$ 1). Son, pues, los lugares cuya inmunidad quedaría asegurada por un eventual acuerdo, inmunidad que no es una extraterritorialidad sino que, como lo entiende el concordato con la República Eslovaca (2000, art. 5. 2), "consiste en impedir usarlos para otros fines que no sean conformes al derecho canónico, e impedir la violación de la propia dignidad de ellos".

Tema diverso es la entrada, examen y registro de los lugares religiosos. Por de pronto, según el Código Procesal Penal, "toda actuación del procedimiento que privare al imputado o a un tercero del ejercicio de los derechos que la Constitución asegura, o lo restringiere o perturbare, requerirá de autorización judicial previa. En consecuencia, cuando una diligencia de investigación pudiere producir alguno de tales efectos, el fiscal deberá solicitar previamente autorización al juez de garantía" (art. 9 inc. $1^{\circ}$ ), la que, en caso de urgencia, podrá solicitarse y otorgarse por cualquier medio idóneo al efecto, como teléfono, fax, correo electrónico u otro (art. 9 inc. $2^{\circ}$ ). Para tal registro, en consecuencia, se requerirá la previa autorización judicial. Además, para proceder al examen y registro de lugares religiosos, el fiscal deberá oficiar previamente a la autoridad o persona a cuyo cargo estuviere, informando de la práctica de la actuación (art. 209 inc. $1^{\circ}$ ), comunicación que deberá ser remitida con al menos 48 horas de anticipación "y contendrá las señas de lo que hubiere de ser objeto del registro. En el mismo aviso se indicarán las personas que acompañarán al fiscal e invitará a la autoridad o persona a cargo del lugar a presenciar la actuación o nombrar a alguna persona que asista" (art. 209 inc. $3^{\circ}$ ). Sin embargo, la misma norma otorga la excepción, pues dicho aviso hay que darlo "a menos que fuere de temer que por dicho aviso pudiere frustrarse la diligencia" (art. 209 inc. $\left.2^{\circ}\right)$. El temor de frustración de la diligencia lo califica el mismo fiscal, por lo que la llegada intempestiva de agentes del Estado a algún lugar religioso está prevista por la misma norma.

A la luz de estos preceptos no me parece que pudiera establecerse en un eventual acuerdo con la Santa Sede una norma similar a la del acuerdo español sobre asuntos jurídicos (1979, art. 1. 6) según la cual la inmunidad se extiende a los archivos, registros y otros documentos pertenecientes a la Conferencia episcopal española, a las curias episcopales, a las 
curias de los superiores mayores de órdenes o congregaciones religiosas, a parroquias y a otras instituciones o entidades eclesiásticas, a menos que la inmunidad la entendamos en los términos definidos en el concordato eslovaco.

Me parece que una norma concordataria debería contemplar esta inmunidad la que, siguiendo el reciente acuerdo con Brasil (2008, art. 7), podría concebirse en los siguientes términos:

"\$ 1. La República de Chile garantiza la inviolabilidad de los lugares que, conforme al derecho canónico, son lugares sagrados, asi como sus liturgias, simbolos, imágenes y objetos cultuales.

$\$ 2$. Las altas partes entienden por inviolabilidad, la protección que impida que los lugares y objetos referidos en el parágrafo anterior sean usados para otros fines que no estén conformes al derecho canónico, y que impida la violación de la propia dignidad".

\section{9) ASistenCia RELigiosa a las FUERZAS ARMADAS}

La asistencia religiosa a las Fuerzas Armadas estaba expresamente regulada en el artículo 11 del Proyecto I, repetido en los mismos términos por el Proyecto $\mathrm{II}^{49}$. El proyecto del nuncio omitía, en la última frase, el adjetivo "militar" que en los proyectos gubernamentales calificaba a la palabra "servicio" omisión que podía dificultar la comprensión de dicha frase. Cuando se redactaban estos proyectos, la asistencia religiosa se extendía al ejército y la armada, y estaba entregada al vicariato castrense, creado por la ley $2.463^{50}$, después que Pío X, mediante el breve In hac Beatissii Petri Cathedra, de 3 de mayo de 1910, creara el vicariato castrense para Chile ${ }^{51}$. En la actualidad, como consecuencia de la nueva estructura canónica que la Iglesia ha dado a la asistencia religiosa militar mediante la constitución apostólica de Juan Pablo II Spirituali militum curae

49 Proyecto I, art. 11; Proyecto II, art. 10: "El Ejército de Chile gozará de todas las exenciones que según las prescripciones del derecho canónico otorga la Santa Sede a otros ejércitos. Los capellanes castrenses, en su actuación referentes a los militares y sus familias, tendrán los derechos inherentes a la cura de almas y ejercerán las funciones de su ministerio bajo la jurisdicción de un vicario general castrense que tendrá el derecho de escogerlos. La Santa Sede permite que este clero, en lo que se refiere al servicio militar, esté sometido a las autoridades militares".

50 Publicada en Diario Oficial de 15 de febrero de 1911. El Consejo de Estado había aprobado la creación del vicariato castrense el 10 de octubre de 1910.

51 Acta Apostolicae Sedis (1910) No 2, pp. 501-503. Su texto en latín y castellano en GonzÁLEZ Errázuriz, Juan Ignacio (1994) Iglesia y Fuerzas Armadas. Estudio canónico y jurídico sobre la asistencia espiritual a las Fuerzas Armadas en Chile. Santiago: Universidad de los Andes. Colección Jurídica, 314 pp., pp. 273-277. También en Retamal Fuentes, Fernando (2005) Chilensia Pontificia. Monumenta Ecclesiae Chilensia. Santiago: Ediciones Universidad Católica de Chile, vol. II, tomo III, 1004-1764 pp., pp. 1174-1183. 
$(1986)^{52}$, el vicariato castrense ha sido sustituido por el obispado castrense de Chile, conservándose la vigencia de la ley 2.463, si bien, adecuada a la nueva terminología ${ }^{53}$. Conforme al artículo 1 de esta ley, el vicario era nombrado "de acuerdo por Santa Sede y el presidente de la República", modalidad que sigue vigente, ahora, para el obispo castrense. Así, la ley orgánica constitucional sobre las Fuerzas Armadas, dispone en su artículo 6 que "el obispo castrense será nombrado en conformidad a la ley 2.463".

"Recibir asistencia religiosa de su propia confesión donde quiera que se encuentre" es una de las facultades que, para toda persona, significa la libertad religiosa y de culto, "con la correspondiente autonomía e inmunidad de coacción", según lo dispone la ley de entidades religiosas (art. 6 c), la que dispone que "la forma y condiciones del acceso de pastores, sacerdotes y ministros del culto, para otorgar asistencia religiosa en... los establecimientos de las Fuerzas Armadas y de las de Orden y Seguridad", serían reguladas mediante reglamentos que dictaría el presidente de la República a través del ministerio de Defensa Nacional. El reglamento fue dictado el año $2008^{54} \mathrm{y}$, aunque "de conformidad con lo dispuesto en el artículo 20 de la ley $n^{\circ} 19.638^{\prime}$ sus normas se aplicarán "sin perjuicio de la vigencia de los reglamentos relativos a los servicios religiosos de las Fuerzas Armadas y de las de Orden y Seguridad Pública" (art. 1 inc. 2o), por lo que la asistencia religiosa católica regulada desde antes no sufre variaciones, tiene el mérito de precisar algunos conceptos que son válidos también para la asistencia religiosa que brinda la Iglesia católica. Así, "se entenderá por asistencia religiosa, además del culto propiamente tal, la promoción de la vida moral y espiritual del personal de las Fuerzas Armadas y de las de Orden y Seguridad Pública, para la realización humana y vocacional del personal, tanto en lo individual como en lo familiar. Asimismo implica el acompañamiento y apoyo espiritual que se desarrolla en la celebración de ceremonias propias del respectivo credo" (art. 2 inc. 10), además de "implicar la asesoría al mando institucional, cuando éste lo requiera, en lo concerniente a la asistencia religiosa del personal de la fe correspondiente" (art. 2 inc. 2o). Para que esta asistencia pueda desarrollarse expeditamente, "en cada establecimiento de las Fuerzas Armadas y de las de Orden y Seguridad Pública, se propenderá a la habilitación de espacios físicos adecuados para el correcto y ordenado ejercicio de la actividad religiosa" (art. 5 inc. 10). Por su parte, el estatuto del

52 Acta Apostolicae Sedis (1986) No 78, pp. 481-486. Su texto en latín y castellano en GonZÁLEZ (1994) 293-303.

53 Por decreto supremo No 99, de defensa nacional, de 1986. Diario Oficial de 29 de octubre de 1986, se cambió la denominación de Vicariato Castrense de Chile, por la de Obispado Castrense de Chile.

54 Decreto supremo No 155, de defensa nacional, de 2007, Reglamento de asistencia religiosa en establecimientos de las Fuerzas Armadas y de las de Orden y Seguridad Pública. Diario Oficial de 26 de mayo de 2008. 
personal de las Fuerzas Armadas 55 , dispone entre los escalafones de los oficiales existe el escalafón del servicio religioso en el ejército (art. 5); la armada (art. 6) y la fuerza aérea (art. 7).

En lo que mira a la dependencia administrativa es preciso distinguir entre el obispado castrense y los servicios religiosos de las instituciones de las Fuerzas Armadas y de las de Orden y Seguridad Públicas. El obispado castrense "en lo administrativo depende directamente del Ministerio de Defensa Nacional'56. En cuanto a los servicios religiosos de cada instituto armado se ha de estar a lo establecido en los propios reglamentos: en el Ejército, los integrantes del servicio religioso, en lo militar, "dependen de sus correspondientes mandos" 57 ; en la Armada, en lo militar y administrativo el servicio religioso depende de la Dirección General del Personal ${ }^{58}$; en Carabineros, el servicio religioso depende administrativamente de la Dirección de Bienestar y los capellanes, en lo administrativo y demás actuaciones de régimen institucional, de las jefaturas de carabineros correspondientes $^{59}$. Y los capellanes de la Policía de Investigaciones dependen del Departamento social, que depende, a su vez, de la Jefatura social de la Subdirección administrativa ${ }^{60}$.

De esta manera, la centenaria vigencia de las normas reguladoras de la asistencia religiosa católica a las Fuerzas Armadas y de Orden y Seguridad Públicas en Chile, las que conservan su vigencia no obstante la legislación que ha ido complementando la regulación de dicha asistencia religiosa, permiten incorporar en un acuerdo con la Santa Sede una norma referida a esta materia. Es por lo que la norma que propongo es:

"\$ 1. El Estado de Chile reconoce y garantiza a la Iglesia católica el derecho de brindar asistencia religiosa y espiritual a los fieles católicos que sean miembros de las Fuerzas Armadas y de las de Orden y Seguridad Pública, como asimismo a sus familiares, la que estará a cargo del Obispado Castrense de Chile.

"\$2. El obispo castrense será nombrado por el Santo Padre de acuerdo con el Presidente de la República.

"\$3. El Obispado Castrense de Chile dependerá, en lo administrativo, del Ministerio de Defensa Nacional. El clero dependiente del Obispado Castrense de Chile dependerá, en lo que se refiere al servicio, de las autoridades institucionales respectivas".

\footnotetext{
55 Decreto con fuerza de ley No 1, de defensa nacional, de 1997. Diario Oficial de 27 de octubre de 1997.

56 Decreto supremo No 35, de defensa nacional, de 1970, Reglamento Orgánico y de funcionamiento del servicio religioso de las Fuerzas Armadas, art. 4.

Reglamento del servicio religioso del Ejército, art. 9.

Reglamento orgánico del servicio religioso de la Armada, art. 101.

Reglamento de Bienestar para Carabineros de Chile, no 24, art. 51.

Decreto supremo No 41, de defensa nacional, de 1987, que establece el Reglamento orgánico de la policía de investigaciones de Chile. Diario Oficial de 8 de junio de 1987.
} 


\section{0) Matrimonio CANÓNico}

Se trata de la materia que en el decurso de estos tres proyectos sufrió más modificaciones ${ }^{61}$. En el primero de ellos ${ }^{62}$ se disponía que los sacerdotes que bendijeren en Chile matrimonios celebrados conforme al rito católico, debían asegurar "por todos los medios a su alcance" la celebración del matrimonio civil por los contrayentes, debiendo los ordinarios dictar las providencias eficaces que velaran por su cabal observación. El proyecto $\mathrm{II}^{63}$, con un texto más breve, daba un paso decidido en pro de la precedencia del matrimonio civil respecto del canónico, disponiendo que "los sacerdotes que bendijeren en Chile matrimonios celebrados conforme al rito católico, lo harán una vez presentado el certificado que acredite la celebración del matrimonio civil'. El nuncio reformuló por completo la norma no solo dando validez civil al matrimonio canónico, sino también al bautismo ${ }^{64}$.

Poco o nada se ha avanzado en esta materia, pues hasta el día de hoy el matrimonio canónico no ha sido reconocido por el Estado. Es cierto que durante la discusión de la nueva ley de matrimonio civil se planteó esta posibilidad, reconocimiento que, por lo demás, se proyectaba a los matrimonios celebrados por todas las entidades religiosas que gozasen de personalidad jurídica de derecho público, pero la redacción final del artículo 20 de la ley frustró dicho intento. En otras sedes he abordado esta materia ${ }^{65}$ por lo que no corresponde repetirla aquí, pero parece claro que

61 Salinas Araneda, Carlos (2013) "El matrimonio canónico en los proyectos de concordato entre Chile y la Santa Sede de 1928”. En Mondaca Miranda, Alexis; Aedo Barrena, Cristián (coordinadores): Nuevos horizontes del derecho privado. Santiago: Librotecnia, 428 pp., pp. 123-142.

62 Proyecto I, art. 12: "Los sacerdotes que bendijeren en Chile matrimonios celebrados conforme al rito católico asegurarán por todos los medios a su alcance la celebración por los contrayentes de matrimonio civil conforme a la ley chilena, y los ordinarios dictarán en igual sentido providencias eficaces y velarán por su cabal observación".

63 Proyecto II, art. 11: "Los sacerdotes, que bendijeren en Chile matrimonios celebrados conforma al rito católico, lo harán una vez presentado el certificado que acredite la celebración del matrimonio civil'.

64 Proyecto III, art. 11: "[inc. $1^{\circ}$ ] Los matrimonios celebrados en conformidad con la ley chilena por ministros del culto católico, producirán efectos civiles. [inc. 20] Los bautismos administrados por dichos ministros producirán efectos iguales a las inscripciones de nacimientos efectuadas en el registro civil, siempre que sean notificados al oficial de la circunscripción respectiva. [inc. $3^{\circ}$ ] Los ministros de culto católico tendrán la obligación de notificar al respectivo oficial del registro civil los dichos matrimonios y los bautismos, en el plazo y en la forma que será determinada por el gobierno de Chile, de acuerdo con la competente autoridad eclesiástica".

65 Salinas Araneda, Carlos (2004) "Matrimonio civil y matrimonio religioso". En Pontificia Universidad Católica de Valparaíso, Facultad de Derecho: El nuevo derecho chileno del matrimonio (ley $n^{o} 19.947$ de 2004). Santiago: Editorial Jurídica de Chile, 418 pp., pp. 49-100; ahora en Salinas Araneda, Carlos (2009) El matrimonio religioso ante el derecho chileno. Estudios y problemas. Valparaíso: Ediciones Universitarias de Valparaíso, Pontificia Universidad Católica de Valparaíso, 263 pp., pp. 43-85; Salinas Araneda, Carlos (2005) "El fracasado intento de reconocer el matrimonio religioso en la nueva ley chilena de matrimonio civil". Revista Española de Derecho Canónico. Vol. 62 No 159, pp. 663-691; Salinas Araneda, 
dicho reconocimiento no se ha producido si se considera que las gestiones previas al matrimonio realizadas ante la entidad religiosa no tienen ningún reconocimiento por el Estado, pues se precisa realizarlas ante el oficial civil, y los efectos civiles de dichos matrimonios se producen "desde su inscripción ante un oficial del Registro Civil” (inc. $1^{\circ}$ i.f.), inscripción que no es un simple trámite administrativo, sino que reviste una formalidad similar a la celebración del matrimonio civil. Con todo, es meritorio que el tema haya vuelto a discutirse y, aun cuando constituye una materia todavía pendiente, está lejos de haberse agotado, especialmente si se considera que la ley de entidades religiosa, entre las facultades que considera comprendidas en el derecho de libertad religiosa y de culto a nivel personal, está la de "celebrar sus ritos" (art. 6 b).

¿Correspondería en un acuerdo con la Santa Sede incorporar una norma referida al matrimonio? Pienso que sí, pero teniendo presente que en nuestra legislación el reconocimiento civil del matrimonio religioso en general y canónico en particular no se ha producido o, por lo menos, es discutible. Desde esta perspectiva, la norma que se incorpore en un acuerdo, al tiempo que reconozca la situación existente, debería ser más bien programática, concebida en estos términos:

"\$1. Los ministros de culto católicos seguirán cumpliendo la tarea de instruir a los fieles para que, sin perjuicio del matrimonio religioso, celebren también matrimonio conforme a la ley de matrimonio civil.

"\$ 2. El Estado de Chile pondrá los medios que le correspondan para obtener el reconocimiento civil de los matrimonios que se celebren conforme al rito católico, en igualdad de condiciones con los celebrados conforme a otros ritos religiosos".

\section{1) Obispado CUYO OBISPO RESIDA FUERA DE CHILE}

El artículo 14 del Proyecto I ${ }^{66}$ disponía que "ninguna parte del territorio de Chile" dependería de un obispo residente fuera de las fronteras chilenas, expresión, más bien geográfica, que fue sustituida en el Proyecto $\mathrm{II}^{67}$ por la de "Ninguna jurisdicción eclesiástica del territorio de Chile", que fue la que recogió textualmente el Proyecto III. Si nos situamos en la época en que se redactan estos proyectos, mayo de 1928, aún estaba

Carlos (2010) "El reconocimiento del matrimonio religioso en el derecho positivo del Estado de Chile: un viejo tema aún pendiente". Revista de Derecho de la Universidad Austral. No 23, pp. 59-78.

66 Proyecto I, art. 14: "Ninguna parte del territorio de Chile dependerá de un obispo que tenga su residencia fuera de las fronteras de la República".

67 Proyecto II, art. 12; Proyecto III, art. 12: "Ninguna jurisdicción eclesiástica del territorio de Chile dependerá de un obispo que tenga su residencia fuera de las fronteras de la República". 
sin resolverse la situación de las provincias de Tacna y Arica, sometidas políticamente a Chile, pero eclesiásticamente al obispo de Arequipa, este artículo venía a solucionar un problema no menor que se había suscitado en dichas provincias ${ }^{68}$.

Parece claro que este artículo venía a ofrecer una solución al conflicto suscitado en los territorios ocupados por el ejército chileno durante la Guerra del Pacífico, problema que poco después de la redacción de estos proyectos quedó solucionado, mediante el Tratado de Lima, celebrado en dicha ciudad el 3 de junio de $1929^{69}$ en el que se estableció que la provincia de Tacna se reincorporaba a Perú permaneciendo la de Arica en poder de Chile. Cabe preguntarse si en un acuerdo con la Santa Sede, una cláusula como la que se encontraba en los proyectos podría estar presente. Parece que la respuesta ha de ser afirmativa, pues, una simple mirada a los concordatos vigentes, permite encontrarla reproducida en algunos de ellos, tanto en territorios europeos como España (1979, acuerdo sobre cuestiones jurídicas, art. I. 2 inc. 3o), Italia (1984, art. 3. 1), Polonia (1993, art. 6. 2), Eslovenia (2001, art. 4 inc. 2o), Portugal (2004, art. 9. 5) como en concordatos latinoamericanos como Venezuela (1964, art. V inc. $2^{\circ}$ ), Perú (1980, art. V), incluso tan recientes como el de Brasil (2008, art. 4). Es por lo que un artículo similar tiene cabida en un acuerdo chileno, cuyo tenor podría ser el siguiente: "Ninguna parte del territorio de Chile dependerá de un obispo que tenga residencia fuera de las fronteras de la República".

\section{2) CREACIÓN DE BENEFICIOS ECLESIÁSTICOS Y COMUNIDAdES RELIGIOSAS}

El artículo 15 del Proyecto I, que pasó casi con el mismo texto a ser el artículo 13 del Proyecto $\mathrm{II}^{70}$, reconocía a las autoridades eclesiásticas el derecho de crear beneficios eclesiásticos y comunidades religiosas, si bien establecía dos limitaciones: i) el establecimiento de nuevas comunidades religiosas requería autorización del gobierno; ii) los extranjeros no podían ser superiores provinciales de comunidades religiosas de varones,

Pérez Canto, Julio (1918) El conflicto después de la victoria. Recuerdos e impresiones de un ex diplomático chileno en el Perú. La última discusión del problema de Tacna y Arica. Santiago: Zig-Zag, 597 pp., pp. 486-498.

69 Su texto en Diario Oficial de 16 de agosto de 1929.

70 Proyecto I, art. 15; Proyecto II, art. 13: “[inc. 10] La creación o modificación de los beneficios eclesiásticos, y de las comunidades religiosas, como también de sus casas y establecimientos dependerá de las autoridades eclesiásticas competentes. [inc. 20] Para el establecimiento en Chile de nuevas comunidades religiosas se requiere autorización del gobierno. [inc. $3^{\circ}$ ] Los extranjeros no podrán desempeñar los cargos de superiores de provincias de las comunidades religiosas de varones establecidas en Chile sin haber obtenido previamente autorización del gobierno". 
su autorización del gobierno. En el proyecto del nuncio ${ }^{71}$ se dejaban en buena parte de lado las exigencias neorregalistas del gobierno de Chile, sustituyendo la autorización del gobierno para el establecimiento de nuevas comunidades religiosas por una simple notificación y eliminando derechamente la limitación de los extranjeros.

En Chile, producida que fue la separación entre la Iglesia y el Estado, la libertad de la Iglesia en esta materia ha sido total, sin necesidad alguna de interactuar con las autoridades del Estado ni antes ni después de las decisiones, libertad que el Estado no ha dudado en reconocer. De hecho, el mismo día que entró en vigencia la Constitución de 1925 en la que se sancionaba constitucionalmente la separación entre el Estado y la Iglesia, la Santa Sede creó siete obispados ${ }^{72}$, sin pedir el parecer del gobierno, algunos de los cuales hacía tiempo que se buscaba erigir, pero que no habían podido erigirse por no contar con la aprobación gubernamental, como el obispado de Valparaíso. Cuando ello ocurrió, no hubo protesta oficial del gobierno; al menos no se conoce. Parece pues, adecuado, al igual que en el moderno derecho concordatario, un artículo en el que esta libertad de la que la Iglesia ha gozado y que el Estado de Chile ha reconocido, sea reconocida explícitamente, con un artículo cuya redacción podría ser la siguiente:

"\$1. El Estado de Chile reconoce a la Iglesia católica el derecho de organizarse libremente, pudiendo crear, modificar o suprimir diócesis, parroquias y otras circunscripciones territoriales, que gozarán de personalidad juridica de derecho público en cuanto la tengan canónica.

"\$2. De la misma manera, puede libremente erigir, aprobar, modificar y suprimir órdenes, congregaciones religiosas, otros Institutos de vida consagradas y otras instituciones y entidades eclesiásticas".

\section{3) NOMBRAMIENTO DE OBISPOS}

El artículo 16 del Proyecto ${ }^{73}$ regulaba el nombramiento de los obispos y pasó, con modificaciones, a ser el artículo 14 del Proyecto $\mathrm{II}^{74}$ : i)

$71 \quad$ Proyecto III, art. 13: "[inc. 10] La creación y modificación de los beneficios eclesiásticos y de las comunidades religiosas, como también de sus casas y establecimientos, dependerá de las autoridades eclesiásticas competentes. "[inc. 20] Para el establecimiento en Chile de nuevas comunidades religiosas se pondrá en conocimiento del gobierno el auto de erección o autorización del ordinario".

72 Los obispados de Valparaíso, San Felipe, Rancagua, Temuco, Linares, Chillán y Talca.

73 Proyecto I, art. 16: "La designación de arzobispo y obispo corresponde a la Santa Sede. Su Santidad se dignará consultar al presidente de la República antes de nombrar al arzobispo y a los obispos diocesanos, a los coadjutores con derecho de sucesión y al vicario general castrense, a fin de cerciorarse de que el presidente no tiene objeciones de carácter politico que oponer a los candidatos".

$74 \quad$ Proyecto II, art. 14: "La designación de arzobispo y obispos corresponde a la Santa Sede. Su Santidad se dignará consultar al presidente de la República antes de nombrar 
entre los nombramientos que la Santa Sede tenía que consultar al gobierno se agregaron los capellanes militares; y en cuanto a las objeciones que podía oponer el Presidente de la República, se eliminó el adjetivo políticas, con lo que se ampliaba la naturaleza de las mismas y la posibilidad de nuevas objeciones. Se trata de un cambio no menor que hay que situar en la tendencia neorregalista del gobierno chileno que el proyecto del nuncio $^{75}$ volvía a encausar al calificar de nuevo la naturaleza de las posibles objeciones como políticas. El inciso segundo del Proyecto III no estaba en los proyectos chilenos, y con él se trataba de diseñar el procedimiento a seguir en cada caso. Hay que tener presente, sin embargo, que en la redacción de este inciso hay un "no" que sobra, pues las objeciones deberían tomarse en cuenta cuando ellas eran fundadas, pues si eran infundadas, no cabía considerarlas.

Una vez que se produjo en 1925 la separación entre la Iglesia y el Estado, y una vez que, como acabo de decir, el mismo día en que la nueva Constitución entraba en vigencia, la Santa Sede creó siete nuevos obispados, procedió poco después a nombrar a los obispos residenciales que debían dirigir cada una de las nuevas diócesis, dos de los cuales eran de nueva creación, porque los otros cinco eran traslados; pero, al hacerlo, actuó con la libertad que dicha separación le otorgaba, sin hacer consulta alguna al gobierno, procedimiento que, inaugurado en dicha oportunidad sin protesta por parte del gobierno, ha seguido la Santa Sede hasta el día de hoy. En la práctica, la Santa Sede notifica al gobierno el nombre del obispo ya designado, el día anterior a su publicación, como un mero gesto de cortesía a efectos de que el gobierno no se entere del nombramiento por la prensa ${ }^{76}$. Tratándose de una simple práctica de hecho, parece conveniente dejarla escriturada en un acuerdo.

Sin perjuicio de lo anterior, me parece que resulta adecuado recoger por escrito el reconocimiento hecho por el Estado de Chile del derecho que le corresponde a la Iglesia de nombrar libremente a sus obispos. Se trata, en todo caso, de un derecho que está reconocido en la ley de entidades religiosas cuando afirma que, en virtud de la libertad religiosa y de

al arzobispo y a los obispos diocesanos, a los coadjutores con derecho de sucesión, al vicario general castrense y sus capellanes, a fin de cerciorarse de que el presidente no tiene objeciones que oponer a los candidatos".

75 Proyecto III, art. 14: "[inc. $1^{\circ}$ ] La designación del arzobispo y de los obispos corresponde a la Santa Sede, la cual antes de nombrar al arzobispo, a los obispos diocesanos, a los coadjutores con derecho de sucesión y al vicario general castrense consultará al gobierno de la Repuiblica, para cerciorarse de que éste no tiene objeciones de orden politico contra los candidatos. [inc. $2^{\circ}$ ] El gobierno de Chile manifestará sus objeciones, si las tuviere, en el plazo de un mes desde la fecha de la consulta, y la Santa Sede las tomará en la debida cuenta, a menos que, efectuada una rigurosa encuesta, no le resulten infundadas. En este caso, y en el caso de que, transcurrido el dicho plazo, el gobierno no haya hecho observación alguna, la Santa Sede procederá al nombramiento". 
culto, se reconoce a las entidades religiosas plena autonomía para el desarrollo de sus funciones propias y, entre otras, "establecer su propia organización interna y jerarquia; capacitar, nombrar, elegir y designar en cargos y jerarquias a las personas que correspondan y determinar sus denominaciones" (art. $7 \mathrm{~b})$.

Conforme a lo anterior, me parece que en un futuro acuerdo entre Chile y la Santa Sede podría incluir un artículo que, recogiendo la práctica permanente llevada adelante desde 1925, se formule de la manera la siguiente:

"\$ 1. El Estado de Chile reconoce el derecho exclusivo de la Santa Sede de proveer libremente los oficios eclesiásticos según el derecho canónico, en particular, decidir independientemente y exclusivamente la elección de candidatos para el ministerio episcopal, asi como el nombramiento, traslado, remoción y renuncia de los obispos.

"\$2. Antes de la publicación del nombramiento de los obispos diocesanos, la Santa Sede lo comunicará, en vía reservada, al gobierno chileno".

\section{4) ENSEŃANZA RELIGIOSA}

El tema de la enseñanza religiosa estaba regulado en el artículo 18 del Proyecto I, que con el mismo texto pasó a ser el artículo 16 del Proyecto $\mathrm{II}^{77}$. El Proyecto del nuncio ${ }^{78}$ introdujo algunas modificaciones que explicitaban el contenido de los artículos anteriores y se cambiaba la fórmula utilizada, pues, mientras en los proyectos del gobierno tan solo se afirmaba que la enseñanza religiosa figuraría en los planes de estudio, ahora se agregaba que la misma sería "obligatoria en todos los cursos y para todos los alumnos" cuyos padres no manifestaren "por escrito" el deseo de no recibirla, exigencia formal que no aparecía en los proyectos del gobierno en los que los padres que querían enseñanza religiosa para sus hijos eran los que tenían que pedirla. Y en el inciso segundo se agregaba la referen-

77 Proyecto I, art. 18; Proyecto II, art. 16: "La enseñanza religiosa figurará en los planes de estudio de todas las escuelas públicas de Chile, para los alumnos cuyos padres o guardadores manifiesten al director del establecimiento su deseo de que la reciban sus hijos o pupilos. Darán esta enseñanza maestros nombrados de entre las personas autorizadas por los ordinarios para enseñar religión, y en caso de que el ordinario respectivo retire la autorización ya dada a un maestro, éste quedará privado del derecho de enseñar religión”.

78 Proyecto III, art. 16: "[inc. 1] La enseñanza de la religión católica figurará en los planes de estudio de los establecimientos de instrucción primaria, secundaria y especial del Estado, y será obligatoria en todos los cursos y para todos los alumnos, cuyos padres o guardadores no manifiesten por escrito al director del establecimiento respectivo el deseo de que no la reciban sus hijoso pupilos. "[inc. 20] Los textos y el programa de esta enseñanza serán fijados por la autoridad eclesiástica y los profesores serán nombrados de entre las personas autorizadas por los ordinarios, que podrán retirar, cuando lo estimen necesario, la autorización ya dada a un profesor, quedando éste, por el hecho, inhabilitado para enseñar religión". 
cia a los textos y el programa de esta enseñanza que serían fijados por la autoridad eclesiástica, lo que estaba ausente en los proyectos del gobierno. Nada se decía, sin embargo, de la posibilidad de la Iglesia católica de establecer sus propios establecimientos de educación.

Aunque la enseńanza religiosa en las escuelas y colegios no tiene consagración constitucional, ella está debidamente amparada por la misma Constitución tanto por garantizar a todas las personas el derecho a la educación que "tiene por objeto el pleno desarrollo de la persona en las distintas etapas de su vida" (art. $19 \mathrm{n}^{\mathrm{o}} 10$ ) como la libertad religiosa y de cultos (art. $19 \mathrm{n}^{\circ}$ 6). Por su parte, la ley de entidades religiosas establece que la libertad religiosa y de culto significa para toda persona "recibir e impartir enseñanza o información religiosa por cualquier medio, elegir para si -y los padres para los menores no emancipados y los guardadores para los incapaces bajo su tuición y cuidado- la educación religiosa y moral que esté de acuerdo con sus propias convicciones" (art. $6 \mathrm{~d}$ ). Y la misma ley reconoce a las entidades religiosas la facultad de "enunciar, comunicar y difundir de palabra, por escrito o por cualquier medio, su propio credo y manifestar su doctrina" (art. 7 c), además de "fundar, mantener y dirigir en forma autónoma institutos de formación y de estudios teológicos o doctrinales" y también "instituciones educacionales" (art. 8 a).

La ley orgánica constitucional de enseñanza ${ }^{79}$ define la educación como un proceso permanente que abarca las distintas etapas de la vida de las personas, con la finalidad de alcanzar, entre otros, "su desarrollo moral... espiritual... y el cultivo de valores..." (art. 2 inc. $1^{\circ}$ ), correspondiéndole preferentemente a los padres el derecho y el deber de educar a sus hijos, teniendo el Estado "el deber de otorgar especial protección al ejercicio de este derecho" (art. 2 inc. $2^{\circ}$ ). Corresponde también al Presidente de la República establecer los objetivos fundamentales y los contenidos mínimos obligatorios de cada uno de los años de estudio de las enseñanzas básica y media (art. 18 inc. 10) ${ }^{80}$; en lo que me interesa, dichos principios, comunes para ambas, "tienen por base la convicción fundamental de que... la perfectibilidad inherente a la naturaleza humana se despliega en procesos... de búsqueda permanente de la trascendencia, los que otorgan sentido a

79 Ley No 18.962. Diario Oficial de 10 de marzo de 1990, con modificaciones en 1991 y 2005. Su texto sistematizado fue fijado por el decreto con fuerza de ley 1, de educación, de 2005.Diario Oficial de 21 de febrero de 2006. Salinas Araneda, Carlos (2010) "Estatuto jurídico de la enseñanza de la religión en Chile”. En Asiaín Pereira, Carmen (coordinadora): Religión en la educación pública. Análisis comparativo de su regulación jurídica en las Américas, Europa, Israel. Madrid: Fundación Universitaria Española, 548 pp., pp. 137-164.

80 Para la educación básica, decreto suprema No 40 de educación, de 1996. Diario Oficial de 3 de febrero de 1996, con modificaciones posteriores, pero que en materia de enseñanza de la religión no ha sufrido cambios. Para le educación media, decreto supremo No 220 de educación, de 1998. Diario Oficial de 18 de mayo de 1998, con modificaciones posteriores, pero que en materia de enseñanza de la religión no tuvo modificaciones. 
la existencia personal y colectiva" (Principios valóricos [educación media] $\mathrm{n}^{\circ}$ 4; [educación básica] no 1.6) por lo que la educación "debe contribuir a forjar en ellos el carácter moral regidos por el amor, la solidaridad, la tolerancia, la verdad, la justicia, la belleza, el sentido de nacionalidad y el afán de trascendencia personal' (Principios valóricos [educación media] no 5; [educación básica $\mathrm{n}^{\circ} 1.7$ ]).

Entre las áreas temáticas reguladas por estas normas está la religión, con la que se trata de fortalecer el desarrollo integral de la persona dentro de una comprensión de la condición material, espiritual y trascendente del hombre, de un recto cultivo y conciencia de los valores morales y religiosos, y del desarrollo de una fe que concite en niños y jóvenes de sólida inclinación por buscar lo trascendente, por conocer y amar a Dios. A la luz de estos principios, la enseñanza de la religión de los establecimientos educacionales de la república está regulada en el decreto supremo 924 del Ministerio de Educación, de $1983^{81}$, según el cual la asignatura de religión tiene el carácter de obligatoria en cuanto a que los establecimientos educacionales deben ofrecerla, pero es optativa para el alumno y la familia. Los programas de religión serán formulados por las autoridades del culto correspondiente y aprobados por el Ministerio de Educación ${ }^{82}$ y los profesores requieren de un certificado de idoneidad otorgado por la autoridad religiosa respectiva ${ }^{83}$ quien decide cuándo de carece de dicha idoneidad, lo que ha sido ratificado por la jurisprudencia ${ }^{84}$.

Existiendo, pues, una aceptación amplia de la enseñanza religiosa en la educación de niños y jóvenes en la legislación chilena, parece adecuado un artículo que recoja no solo el derecho de los católicos de recibir enseñanza religiosa católica en los establecimientos educacionales, sino que, además, se reconozca el derecho de la Iglesia, por una parte, de erigir instituciones educacionales y, por otra, de erigir seminarios e institutos de formación y estudios teológicos. De esta manera el tenor de este artículo puede ser el siguiente:

$81 \quad$ Diario Oficial de 7 de enero de 1984.

82 Decreto supremo No 594 de educación, de 1996, aprueba programa de religión católica para los cursos de $1^{\circ}$ a $8^{\circ}$ de enseñanza básica. Diario Oficial de 18 de noviembre de 1996; decreto supremo No 158 de educación, de 1983.Diario Oficial de 26 de agosto de 1983, aprueba programa de religión católica para la educación media humanístico-científica.

83 El decreto supremo No 352 de educación, de 2003. Diario Oficial de 12 de marzo de 2004, que reglamenta el ejercicio de la función docente, dispone en su artículo 5 que "las personas que realicen clases de religión deberán cumplir con los requisitos especiales que establecen las disposiciones contenidas en el decreto supremo de educación no 924, de 1983".

84 Candia Falcón, Gonzalo (2008) "Idoneidad de los profesores de religión: una consecuencia práctica de la libertad religiosa”. Jurisprudencia al día LexisNexis, Vol. 2 No 84, pp. 1053-1054; Precht, Jorge (2008) "Idoneidad del profesor de religión. Sentencias Cortes de Apelaciones de San Miguel y Suprema de 27 de noviembre de 2007 y 17 de abril de 2008". Revista Chilena de Derecho. Vol. 35 No 3, pp. 521-524. 
"\$ 1. La República de Chile, a la luz del derecho de libertad religiosa, respeta el derecho fundamental de los padres a la educación religiosa de sus hijos, y les garantiza a ellos y a los guardadores respecto de sus pupilos la enseñanza de la religión católica en todos los establecimientos de educación pre-escolar, básica, media y profesional, la que será obligatoria para todos los alumnos cuyos padres o guardadores no manifiesten por escrito al director del establecimiento respectivo el deseo de que no la reciban sus hijos o pupilos.

"\$ 2. Los textos y el programa de esta enseñanza serán fijados por la autoridad eclesiástica; los profesores serán nombrados de entre las personas autorizadas por los ordinarios, quienes podrán retirar, cuando lo estimen necesario, la autorización ya dada a un profesor, quedando éste inhabilitado para enseñar religión.

"\$ 3. El Estado de Chile reconoce a la Iglesia católica el derecho de erigir instituciones educacionales de cualquier grado y de administrarlas según sus propias normas, respetando las disposiciones legales chilenas. Le reconoce, además, el derecho de constituir y dirigir seminarios, institutos de formación y de estudios teológicos o doctrinales para la formación de los sacerdotes, religiosos y laicos.

"\$ 4. La convalidación y reconocimiento por parte del Estado de los estudios y grados realizados y obtenidos en dichos centros se realizarán de acuerdo con las normas generales sobre la materia, sin perjuicio de acuerdos directos entre las autoridades estatales y eclesiásticas correspondientes".

\section{5) ACTOS ADMINISTRATIVOS SOBRE BIENES ECLESIÁSTICOS}

El artículo 19 del Proyecto I, recogido textualmente en el Proyecto II $^{85}$ y reproducido con leves cambios de redacción en el Proyecto III ${ }^{86}$,

85 Proyecto I, art. 19; Proyecto II, art. 17: “[inc. 10] Los bienes pertenecientes a la Iglesia no serán sometidos a resoluciones o actos jurídicos que puedan modificar su destinación sin consentimiento de las autoridades eclesiásticas, salvo en los casos previstos en la ley respecto de expropiaciones por causa de utilidad pública. [inc. 20] En estos casos la destinación de los inmuebles consagrados exclusivamente al culto divino, tales como las iglesias y sus dotaciones, será modificada una vez que la respectiva autoridad eclesiástica, notificada oportunamente, haya podido levantarles su carácter sagrado. [inc. $3^{\circ}$ ] No se procederá a ninguna construcción, modificación o restauración de iglesias o capillas sino conforme a las prescripciones del derecho común, que estén en vigencia con respecto a tales trabajos".

86 Proyecto III, art. 17: “[inc. 10] Los bienes pertenecientes a la Iglesia no serán sometidos a resoluciones o actos jurídicos que puedan modificar su destinación, sin el consentimiento de las autoridades eclesiásticas, salvo en los casos previstos en la ley referente a expropiaciones por causa de utilidad pública. [inc. 20] En estos casos la destinación de los inmuebles consagrados exclusivamente al culto divino, tales como las iglesias y sus dotaciones, será modificada una vez que la respectiva autoridad eclesiástica, notificada oportunamente, haya podido levantarle su carácter sagrado. [inc. $3^{\circ}$ ] La construcción, modificación o restauración de iglesias o capillas quedan sometidas a las normas y a las condiciones de seguridad e higiene fijadas por las leyes y ordenanzas que rijan en Chile sobre la materia". 
regulaba la protección de los bienes eclesiásticos respecto de actos de la autoridad de manera que, sin eximirlos de ella, señala algunas condiciones para su actuación. Por su parte, el artículo 21 del Proyecto I ${ }^{87}$, recogido con una mayor restricción en el artículo 19 del Proyecto II ${ }^{88}$, reconocía la posibilidad de que pudieren establecerse y administrarse cementerios católicos en Chile, artículos que recogía el nuncio en su proyecto ${ }^{89}$ con una redacción que se aproximaba, con cambios de redacción, al texto del Proyecto I.

Dispone el Código de Derecho Canónico, derecho que ha sido reconocido genéricamente por la ley de entidades religiosas en su artículo 20, que "son lugares sagrados aquellos que se destinan al culto divino o a la sepultura de los fieles mediante la dedicación o bendición prescrita por los libros litúrgicos" (can. 1205), de manera que "en un lugar sagrado solo puede admitirse aquello que favorece el ejercicio y el fomento del culto, de la piedad $y$ de la religión, y se prohibe lo que no está en consonancia con la santidad del lugar", si bien el ordinario puede permitir, en casos concretos, otros usos siempre que no sean contrarios a la santidad del lugar (can. 1210); los lugares sagrados pierden su dedicación o bendición "si resultan destruidos en gran parte, o si son reducidos permanentemente a usos profanos por decreto del ordinario o de hecho" (can. 1213). Los cementerios han de considerarse lugares sagrados y el propio código les dedica cuatro cánones (can. 12401243), el primero de los cuales afirma que "donde sea posible, la Iglesia debe tener cementerios propios".

Por su parte, el derecho de propiedad en sus diversas especies, sobre toda clase de bienes corporales e incorporales, está garantizado por la Constitución, de manera que nadie, en caso alguno, puede ser privado de su propiedad, del bien sobre que recae o de alguno de los atributos o facultades del dominio, "sino en virtud de la ley general o especial que autorice la expropiación por causa de utilidad pública o de interés nacional, calificada por el legislador" (art. 19 no 24).

Este artículo no hacía sino que especificar, respecto de los bienes eclesiásticos, en general, y de los lugares sagrados, en particular, la legislación chilena válida para cualquier personas que se encontrase en las situaciones descrita en el artículo proyectado. Pero tenía el mérito de reconocer implícitamente el derecho canónico, al establecer un gesto de cortesía hacia la autoridad eclesiástica para que pudiese poner en acción las normas canónicas antes de la actuación de la autoridad civil. En cuan-

\footnotetext{
87 Proyecto I, art. 21: "Podrán establecerse y administrarse en Chile cementerios católicos de acuerdo con la legislación chilena y el derecho canónico".

88 Proyecto II, art. 19: "Podrán administrarse en Chile los cementerios católicos existentes de acuerdo con la legislación chilena y el derecho canónico".

89 Proyecto III, art. 18: "Los cementerios católicos podrán administrarse libremente en Chile, en conformidad con el Derecho Canónico y con la legislación actualmente en vigor".
} 
to a los cementerios, aunque el tema ha sido conflictivo en las relaciones Iglesia-Estado en Chile, una vez que quedó solucionado no ha vuelto a generar problemas. Más aún, la posibilidad de que en Chile haya empresas comerciales que se dediquen a explotar cementerios permite a la Iglesia seguir cumpliendo con esta finalidad, en la medida que cumpla las exigencias establecidas por la legislación chilena, como vienen haciendo, por ejemplo, los cementerios parroquiales.

A la luz de lo anterior, pienso que este proyecto de artículo de 1928 puede conservarse en términos similares. Me parece, además, que la referencia a los cementerios podría hacerse aquí, sin que fuere necesario un artículo especial. Conforme a esto, su redacción podría ser la siguiente:

"\$ 1. Los bienes pertenecientes a la Iglesia no serán sometidos a resoluciones o actos juridicos que puedan modificar su destinación, sin el consentimiento de las autoridades eclesiásticas, salvo en los casos previstos en la ley referente a expropiaciones por causa de utilidad pública.

"\$2. En estos casos la destinación de los lugares sagrados será modificada una vez que la respectiva autoridad eclesiástica, notificada oportunamente, haya podido levantarle su carácter sagrado.

"\$3. La construcción, modificación o restauración de iglesias o capillas, asi como el establecimiento y administración de los cementerios católicos, quedan sometidas a las normas y a las condiciones de seguridad e higiene fijadas por las leyes y ordenanzas que rijan en Chile sobre la materia asi como al derecho canónico".

\section{6) ACUSACIONES CONTRA ECLESIÁSTICOS POR DELITOS COMUNES}

El artículo 25 del Proyecto I que, sin modificaciones, pasó al Proyecto II con el número 23 y al artículo 23 del Proyecto III, se refería a las acusaciones contra eclesiásticos o religiosos ante los tribunales del Estado por delitos comunes. Se trataba, pues, de un artículo que permanecía en todos los proyectos con la misma fórmula ${ }^{90}$. Era la supervivencia, muy disminuida por cierto, del viejo privilegio del fuero según el cual los eclesiásticos que cometían delitos comunes sancionados por la legislación civil debían ser juzgados por tribunales eclesiásticos. En los proyectos, tan solo se establecía el deber de la autoridad judicial de comunicar el hecho al superior eclesiástico respectivo. Me parece que una norma similar debería tener cabida en un concordato futuro. De hecho, en Chile la justicia penal ha

\footnotetext{
$90 \quad$ Proyecto I, art. 25; Proyecto II, art. 23; Proyecto III, art. 23: "Si algún eclesiástico o religioso fuere acusado ante los tribunales chilenos por crimenes previstos en las leyes penales de la República, el tribunal respectivo informará sin pérdida de tiempo al ordinario correspondiente y le trasmitirá el auto de acusación y, en su oportunidad, la sentencia con sus considerandos".
} 
conocido procesos de esta naturaleza, concluyendo con las respectivas condenas. Pero, en mi opinión, a una norma similar le haría un añadido.

En efecto, conocida es la triste realidad de clérigos y religiosos que, traicionando su consagración, han cometido delitos relacionados con abusos sexuales especialmente con menores. La Iglesia, especialmente a partir del pontificado de Benedicto XVI y bajo el actual pontífice, ha adoptado la política de tolerancia cero, pues, como ambos pontífices lo han reiterado, no hay lugar en la Iglesia para esas personas. Me parece, en consecuencia, que la Iglesia, en un gesto de autenticidad, debería asumir el compromiso de denunciar dichos delitos cuando, después de una indagación seria de los mismos, llegue a la convicción de que hay elementos fundados acerca de la comisión de los mismos y de la responsabilidad que en ellos le quepa a un clérigo o religioso. Por lo demás, ya hay presentado un proyecto de ley en tal sentido en el que, si bien se establece la obligación de los ministros de culto de denunciar los delitos de que conozcan en el ejercicio de sus ministerios, se respeta el secreto de confesión de los sacerdotes católicos ${ }^{91}$. De esta manera, una futura norma concordataria podría concebirse así:

"\$1. Si algún eclesiástico o religioso fuere acusado ante los tribunales chilenos por crimenes previstos en las leyes penales de la República, el tribunal respectivo informará sin pérdida de tiempo al ordinario correspondiente y le trasmitirá el auto de acusación y, en su oportunidad, la sentencia con sus considerandos.

"\$2. Las autoridades eclesiásticas respectivas denunciarán los delitos cometidos por eclesiásticos o religiosos cuando, después de una indagación seria en el fuero externo y respetado el secreto de confesión, lleguen a la convicción de que hay elementos fundados acerca de la comisión de los mismos y de la responsabilidad que en ellos le quepa a un clérigo o religioso".

\section{7) Cláusulas finales}

Las cláusulas finales de los proyectos de concordato de 1928 se referían a la derogación de las normas contrarias al concordato ${ }^{92}$, a la ratifica-

\footnotetext{
91 Proyecto de ley iniciado en moción de los honorables senadores señor Navarro, señora Pérez San Martin y señores Escalona, Horvath y Muñoz Aburto, que obliga a quienes ejercen labores pastorales a denunciar delitos que indica. Boletín no 6.938-07.

92 Proyecto I, art. 27; Proyecto II, art. 25; Proyecto III, art. 25: "Quedan derogadas todas las disposiciones legales, reglamentarias o administrativas vigentes en Chile que fueren contrarias a las que el presente concordato contiene".
} 
ción y canje de ratificaciones ${ }^{93}$ y la vigencia del mismo ${ }^{94}$. Para un futuro acuerdo con la Santa Sede, sugiero las siguientes cláusulas:

En lo referido a la derogación de normas:

"\$ 1. La República de Chile y la Santa Sede procederán a la elaboración, revisión y publicación de la legislación complementaria eventualmente necesaria.

"\$ 2. Para poner en práctica la norma anterior las Altas Partes efectuarán consultas reciprocas".

En lo referido a las ratificaciones:

"El presente Concordato será ratificado según las normas de las Altas Partes contrayentes y entrará en vigencia en el momento de intercambio de los instrumentos de ratificación, a efectuarse lo antes posible".

En lo referido a la vigencia: no incluiría cláusula alguna al respecto, pues ella no se estila en el moderno derecho concordatario.

\section{ANEXO}

\section{AVance de un aCUERdo entre Chile y la SANTa Sede}

[Los artículos aparecen ordenados de una manera diversa a aquella en que fueron presentados en el cuerpo de este artículo.]

Artículo 1

"\$ 1. La República de Chile, sobre la base del derecho de libertad religiosa, reconoce a la Iglesia católica el derecho de desarrollar con plena autonomía su misión apostólica, garantizando el ejercicio público de sus actividades, en conformidad con el ordenamiento juridico chileno.

"\$ 2. La República de Chile asegura a la Iglesia católica y a los organismos que la integran o que de ella dependen según el derecho canónico, el libre ejercicio de su poder espiritual y de su jurisdicción eclesiástica".

\section{Artículo 2}

"\$ 1. El Estado de Chile reconoce la personalidad juridica de derecho público de la Iglesia católica, de la Conferencia Episcopal de Chile, de las personas juridicas canónicas que forman parte de su estructura jerárquica, de

\footnotetext{
93 Proyecto I, art. 28; Proyecto II, art. 26; Proyecto III, 26: "El presente concordato será ratificado y sus ratificaciones serán canjeadas en [Proyecto I: "esta capital"; Proyecto II: "en Roma"; Proyecto III: “...”] tan pronto como sea posible”.

94 Proyecto I, art. 29; Proyecto II, art. 27; Proyecto III, art. 27: "La vigencia de este concordato será de 10 años [Proyecto III: "50 años"] contados desde el día del canje de sus ratificaciones; pero, vencido este término, continuará en vigor hasta que una de las partes signatarias notifique a la otra, con aviso previo de un año, su resolución de ponerle término".
} 
las prelaturas personales, de los Institutos de Vida Consagrada y de las Sociedades de Vida Apostólica.

"\$2. El Estado de Chile reconoce la personalidad jurídica de derecho privado de las demás entidades eclesiales que obtengan personalidad juridica conforme al derecho canónico, lo que será acreditado mediante certificación dela autoridad competente que la haya conferido".

Artículo 3

"\$ 1. La Santa Sede puede comunicarse libremente con los obispos, el clero y los fieles, así como estos pueden hacerlo con la Santa Sede.

"\$2. Los obispos y las otras autoridades eclesiásticas gozan de la misma libertad en relación con el clero y los fieles, con las Conferencias episcopales de otros paises, y también con iglesias particulares, instituciones y personas tanto dentro como fuera del territorio de la República".

Artículo 4

"\$ 1. El Estado de Chile reconoce a la Iglesia católica el derecho de organizarse libremente, pudiendo crear, modificar o suprimir diócesis, parroquias y otras circunscripciones territoriales, que gozarán de personalidad juridica de derecho público en cuanto la tengan canónica.

"\$2. De la misma manera, puede libremente erigir, aprobar, modificar y suprimir órdenes, congregaciones religiosas, otros institutos de vida consagradas y otras instituciones y entidades eclesiásticas".

Artículo 5

"\$ 1. El Estado de Chile reconoce el derecho exclusivo de la Santa Sede de proveer libremente los oficios eclesiásticos según el derecho canónico, en particular, decidir independientemente y exclusivamente la elección de candidatos para el ministerio episcopal, así como el nombramiento, traslado, remoción y renuncia de los obispos.

"\$2. Antes de la publicación del nombramiento de los obispos diocesanos, la Santa Sede lo comunicará, en vía reservada, al gobierno chileno".

Artículo 6

"\$1. Los sacerdotes seculares y regulares y los religiosos profesos estarán exentos del servicio militar obligatorio.

"\$2. Los seminaristas o los novicios de institutos de vida consagrada o de sociedades de vida apostólica, haciendo uso de la modalidad alternativa de servicio militar acordada a los estudiantes, lo realizarán en el servicio religioso de cualquiera de las Fuerzas Armadas o de Orden y Seguridad".

"\$3. En caso de reclutamiento general, quedarán exentos del servicio militar los ordinarios, los párrocos, y los sacerdotes seculares y regulares con cura de almas. Los demás serán asignados al servicio religioso de las tropas o a los servicios de enfermería". 
Artículo 7

"Los eclesiásticos estarán exentos de ejercer funciones o cargos civiles incompatibles con la vocación sacerdotal, en conformidad con el derecho canónico".

Artículo 8

"\$ 1. La República de Chile garantiza la inviolabilidad de los lugares que, conforme al derecho canónico, son lugares sagrados, asi como sus liturgias, simbolos, imágenes y objetos cultuales.

"\$2. Las altas partes entienden por inviolabilidad, la protección que impida que los lugares y objetos referidos en el parágrafo anterior sean usados para otros fines que no estén conformes al derecho canónico, y que impida la violación de la propia dignidad".

\section{Artículo 9}

"\$ 1. El Estado de Chile reconoce y garantiza a la Iglesia católica el derecho de brindar asistencia religiosa y espiritual a los fieles católicos que sean miembros de las Fuerzas Armadas y de las de Orden y Seguridad Pública, como asi mismo a sus familiares, la que estará a cargo del Obispado Castrense de Chile.

"\$ 2. El obispo castrense será nombrado por el Santo Padre de acuerdo con el Presidente de la República.

"\$3. El Obispado Castrense de Chile dependerá, en lo administrativo, del Ministerio de Defensa Nacional. El clero dependiente del Obispado Castrense de Chile dependerá, en lo que se refiere al servicio, de las autoridades institucionales respectivas".

Artículo 10

"\$ 1. Los ministros de culto católicos seguirán cumpliendo la tarea de instruir a los fieles para que, sin perjuicio del matrimonio religioso, celebren también matrimonio conforme a la ley de matrimonio civil.

"\$ 2. El Estado de Chile pondrá los medios que le correspondan para obtener el reconocimiento civil de los matrimonios que se celebren conforme al rito católico, en igualdad de condiciones con los celebrados conforme a otros ritos religiosos".

\section{Artículo 11}

"Ninguna parte del territorio de Chile dependerá de un obispo que tenga residencia fuera de las fronteras de la República".

\section{Artículo 12}

"\$ 1. La República de Chile, a la luz del derecho de libertad religiosa, respeta el derecho fundamental de los padres a la educación religiosa de sus hijos, y les garantiza a ellos y a los guardadores respecto de sus pupilos la 
enseñanza de la religión católica en todos los establecimientos de educación pre-escolar, básica, media y profesional, la que será obligatoria para todos los alumnos cuyos padres o guardadores no manifiesten por escrito al director del establecimiento respectivo el deseo de que no la reciban sus hijos o pupilos.

"\$ 2. Los textos y el programa de esta enseñanza serán fijados por la autoridad eclesiástica; los profesores serán nombrados de entre las personas autorizadas por los Ordinarios, quienes podrán retirar, cuando lo estimen necesario, la autorización ya dada a un profesor, quedando éste inhabilitado para enseñar religión.

"\$3. El Estado de Chile reconoce a la Iglesia católica el derecho de erigir instituciones educacionales de cualquier grado y de administrarlas según sus propias normas, respetando las disposiciones legales chilenas. Le reconoce, además, el derecho de constituir y dirigir seminarios, institutos de formación y de estudios teológicos o doctrinales para la formación de los sacerdotes, religiosos $y$ laicos.

"\$ 4. La convalidación y reconocimiento por parte del Estado de los estudios y grados realizados y obtenidos en dichos centros se realizarán de acuerdo con las normas generales sobre la materia, sin perjuicio de acuerdos directos entre las autoridades estatales y eclesiásticas correspondientes".

Artículo 13

"Las autoridades chilenas asegurarán el resguardo del orden en actos o manifestaciones religiosas en lugares públicos y en las otras circunstancias en que prescriban o permitan tal apoyo las leyes chilenas".

Artículo 14

"\$1. El Estado de Chile reconoce a la Iglesia universal y la Sede Apostólica, a las iglesias particulares y cualquier otra persona jurídica, tanto pública como privada, erigidas conforme al derecho canónico, su calidad de sujetos capaces de adquirir, retener, administrar y enajenar bienes temporales, según el derecho canónica y el derecho de la República de Chile.

"\$2. El Estado reconoce el derecho de la Iglesia católica a recabar libremente de los fieles contribuciones y ofrendas para sostener el culto divino, sustentar honestamente al clero y demás ministros y hacer las obras de apostolado y caridad, sobre todo con los más necesitados".

\section{Artículo 15}

"\$1. Los bienes pertenecientes a la Iglesia no serán sometidos a resoluciones o actos jurídicos que puedan modificar su destinación, sin el consentimiento de las autoridades eclesiásticas, salvo en los casos previstos en la ley referente a expropiaciones por causa de utilidad pública.

"\$2. En estos casos la destinación de los lugares sagrados será modificada una vez que la respectiva autoridad eclesiástica, notificada oportunamente, haya podido levantarle su carácter sagrado. 
"\$3. La construcción, modificación o restauración de iglesias o capillas, asi como la administración de los cementerios católicos, quedan sometidas a las normas y a las condiciones de seguridad e higiene fijadas por las leyes y ordenanzas que rijan en Chile sobre la materia asi como al derecho canónico".

\section{Artículo 16}

"\$ 1. Las personas naturales y juridicas regidas por el derecho canónico quedan sometidos a impuestos del mismo modo que las personas y los bienes de los ciudadanos de la República y que las personas jurídicas.

"\$ 2. Los templos y sus dependencias dedicados exclusivamente al servicio del culto de la Iglesia católica estarán exentos de contribuciones. Los demás edificios y dependencias de propiedad de personas juridicas erigidas conforme al derecho canónico, quedarán exentos de contribuciones conforme al derecho común.

"\$3. La Iglesia católica y las personas juridicas regidas por el derecho canónico tendrán los mismos derechos, exenciones y beneficios tributarios que la Constitución Politica de la República, las leyes y reglamentos vigentes otorguen y reconozcan a otras iglesias, confesiones e instituciones religiosas existentes en el pais".

\section{Artículo 17}

"\$ 1. Si algún eclesiástico o religioso fuere acusado ante los tribunales chilenos por crimenes previstos en las leyes penales de la República, el tribunal respectivo informará sin pérdida de tiempo al ordinario correspondiente y le trasmitirá el auto de acusación y, en su oportunidad, la sentencia con sus considerandos.

"\$2. Las autoridades eclesiásticas respectivas denunciarán los delitos cometidos por eclesiásticos o religiosos cuando, después de una indagación seria en el fuero externo y respetado el secreto de confesión, lleguen a la convicción de que hay elementos fundados acerca de la comisión de los mismos y de la responsabilidad que en ellos le quepa a un clérigo o religioso".

\section{Artículo 18}

"\$ 1. La República de Chile y la Santa Sede procederán a la elaboración, revisión y publicación de la legislación complementaria eventualmente necesaria.

"\$2. Para poner en práctica la norma anterior las Altas Partes efectuarán consultas reciprocas".

Artículo 19

"El presente Concordato será ratificado según las normas de las Altas Partes contrayentes y entrará en vigencia en el momento de intercambio de los instrumentos de ratificación, a efectuarse lo antes posible". 


\section{BIBLIOGRAFÍA}

\section{FUENTES}

- Acordo entre a República Federativa do Brasil e a Santa Sé relativo ao estatuto juridico da Igreja católica no Brasil (2008).

- Actas oficiales de la Comisión Constituyente (1975).

- Código de Derecho Canónico (1983).

- Tratado de Lima. Diario Oficial de 16 de agosto de 1929.

- Ley No 2306. Diario Oficial de 15 de febrero de 1911.

- Ley No 16.271. Diario Oficial de 10 de julio de 1965.

- Ley No 18.962. Diario Oficial de 10 de marzo de 1990.

- Ley No 19.638. Diario Oficial de 14 de octubre de 1999.

- Ley No 19.665. Diario Oficial de 9 de marzo de 2000.

- Decreto Ley No 824. Diario Oficial de 31 de diciembre de 1974.

- Decreto Ley No 2.306. Diario Oficial de 12 de septiembre de 1978.

- Decreto ley No 3.475. Diario Oficial de 4 de septiembre de 1980.

- Decreto con fuerza de ley No 1, de defensa nacional, de 1997. Diario Oficial de 27 de octubre de 1997.

- Decreto supremo No 35, de defensa nacional, de 1970, Reglamento Orgánico y de funcionamiento del servicio religioso de las Fuerzas Armadas.

- Decreto supremo No 2.106, de hacienda, de 1974. Diario Oficial de 16 de enero de 1975.

- Decreto supremo No 158 de educación, de 1983. Diario Oficial de 26 de agosto de 1983.

- Decreto supremo No 924, de educación, de 1983. Diario Oficial de 7 de enero de 1984.

- Decreto supremo No 99, de defensa nacional, de 1986. Diario Oficial de 29 de octubre de 1986.

- Decreto supremo No 41, de defensa nacional, de 1987. Diario Oficial de 8 de junio de 1987.

- Decreto supremo No 40, de educación, de 1996. Diario Oficial de 3 de febrero de 1996.

- Decreto supremo No 594 de educación, de 1996. Diario Oficial de 18 de noviembre de 1996;

- Decreto supremo No 220, de educación, de 1998. Diario Oficial de 18 de mayo de 1998.

- Decreto supremo No 352 de educación, de 2003. Diario Oficial de 12 de marzo de 2004.

- Decreto supremo No 155, de defensa nacional, de 2007. Diario Oficial de 26 de mayo de 2008.

- Reglamento del servicio religioso del Ejército. 
- Reglamento orgánico del servicio religioso de la Armada.

- Reglamento de bienestar para Carabineros de Chile.

- Servicio de Impuestos Internos (2001) Oficio no 313 de 22 de enero, de la subdirección normativa del departamento de impuestos directos.

---- (2012) Circular no 45 de 24 de septiembre.

- Proyecto de ley iniciado en moción de los honorables senadores señor Navarro, señora Pérez San Martín y señores Escalona, Horvath y Muñoz Aburto, que obliga a quienes ejercen labores pastorales a denunciar delitos que indica. Boletín no 6.938-07.

\section{MONOGRAFÍAS}

- Alessandri Rodríguez, Arturo; Somarriva Undurraga, Manuel (1962) Curso de derecho civil. Redactado y puesto al día por Antonio Vodanovic. Santiago: tomo I, vol. 2, 397 pp., pp. 278-285.

- Bolletino della Sala Stampa della Santa Sede, 30 junio 2006 no 0340, en www.vatican.va [consultado el 24 de mayo de 2011].

- Candia Falcón, Gonzalo (2008) "Idoneidad de los profesores de religión: una consecuencia práctica de la libertad religiosa". Jurisprudencia al dia LexisNexis. Vol. 2 No 84, pp. 1053-1054.

- Concilio Vaticano II (1965), Declaración 'Dignitatis humanae', sobre la libertad religiosa. Su texto en castellano en Concilio Vaticano II. Constituciones, decretos, declaraciones, legislación posconciliar (1967) 4a Ed. Madrid: Biblioteca de Autores Cristianos, 1129 pp., pp. 778-804.

- Ducasse Medina, Ignacio (2008) Servidores del Evangelio. Los obispos de Chile 1561-2007. Santiago: Conferencia Episcopal de Chile, 342 pp., pp. 154-155.

- Enchiridion dei concordati. Due secoli dei rapporti Chiesa-Stato (2003) Bologna: Dehoniane, 2257 pp.

- González Errázuriz, Juan Ignacio (1994) Iglesia y Fuerzas Armadas. Estudio canónico y jurídico sobre la asistencia espiritual a las Fuerzas Armadas en Chile. Santiago: Universidad de los Andes. Colección Jurídica, 314 pp.

- Martín de Agar, José T. (2010) I concordati dal 2000 al 2009. Città del Vaticano: Libreria Editrice Vaticana, 317 pp., pp. 42.

- Obispos de Chile (1925) "Pastoral colectiva de los obispos de Chile, sobre la separación de la Iglesia y el Estado". La Revista Católica. Año 25 No 578, pp. 488-491.

- Oviedo Cavada, Carlos (1958) "Negociaciones chilenas sobre convenios con la Santa Sede". Finis Terrae. No 9, pp. 37-53. 
- Oviedo Cavada, Carlos (1962) La misión Irarrázabal en Roma 1847-1850. Estudio histórico-canónico de las relaciones de Iglesia y Estado en Chile. Santiago: Ediciones Universidad Católica de Chile, $450 \mathrm{pp}$.

- Oviedo Cavada, Carlos (1987) "Un siglo de relaciones entre la Santa Sede y Chile. 1822-1925”. Diplomacia. No 39, pp. 18-30.

- Oviedo Cavada, Carlos (1975-1976) "La jerarquía eclesiástica y la separación de la Iglesia y el Estado en 1925". Boletín de la Academia Chilena de la Historia. No 89, pp. 13-22.

- Pacheco Gómez, Máximo (2004) La separación de la Iglesia y el Estado en Chile y la diplomacia vaticana. Santiago: Editorial Andrés Bello, 333 pp.

- Pérez Canto, Julio (1918) El conflicto después de la victoria. Recuerdos e impresiones de un ex diplomático chileno en el Perú. La última discusión del problema de Tacna y Arica. Santiago: Zig-Zag, 597 pp.

- Precht, Jorge (2008) “Idoneidad del profesor de religión. Sentencias Cortes de Apelaciones de San Miguel y Suprema de 27 de noviembre de 2007 y 17 de abril de 2008". Revista Chilena de Derecho. Vol. 35 No 3, pp. 521-524.

- $\quad$ "Representación que hacen a la H. Cámara de Senadores [en 1857] el Ilmo. y Rmo. Señor Arzobispo de la Metrópoli de Santiago de Chile, Dr. D. Rafael Valentín Valdivieso, e Ilustrísimos señores obispos sufragáneos de La Serena y Concepción (1902). En Astorga, José Ramón (recop.), Obras cientificas i literarias del Ilmo. y Rmo. Sr. Don Rafael Valentín Valdivieso, arzobispo de Santiago de Chile. Santiago de Chile, vol. II, pp. 27-58.

- Retamal Fuentes, Fernando (2005) Chilensia Pontificia. Monumenta Ecclesiae Chilensia. Santiago: Ediciones Universidad Católica de Chile, vol. II, tomo III, 1004-1764 pp.

- Salinas Araneda, Carlos (2004) Lecciones de derecho eclesiástico del Estado de Chile. Valparaíso: Ediciones Universitarias de Valparaíso, 474 pp., pp. 263-279.

--- (2004) "Matrimonio civil y matrimonio religioso". En Pontificia Universidad Católica de Valparaíso, Facultad de Derecho: El nuevo derecho chileno del matrimonio (ley $n^{o} 19.947$ de 2004). Santiago: Editorial Jurídica de Chile, 418 pp., pp. 49-100.

--- (2005) "El fracasado intento de reconocer el matrimonio religioso en la nueva ley chilena de matrimonio civil". Revista Española de Derecho Canónico. Vol. 62 No 159, pp. 663-691.

--- (2009) El matrimonio religioso ante el derecho chileno. Estudios y problemas. Valparaíso: Ediciones Universitarias de Valparaíso, Pontificia Universidad Católica de Valparaíso, 263 pp., pp. 43-85. 
--- (2010) "El reconocimiento del matrimonio religioso en el derecho positivo del Estado de Chile: un viejo tema aún pendiente". Revista de Derecho de la Universidad Austral. No 23, pp. 59-78.

- --- (2010) "Estatuto jurídico de la enseñanza de la religión en Chile". En Asiaín Pereira, Carmen (coord.), Religión en la educación pública. Análisis comparativo de su regulación juridica en las Américas, Europa, Israel. Madrid: Fundación Universitaria Española, 548 pp., pp. 137-164.

--- (2012) "Un primer proyecto de concordato entre Chile y la Santa Sede en 1928". Revista Chilena de Derecho. Vol. 39 No 3, pp. 665698.

--- (2013), “El matrimonio canónico en los proyectos de concordato entre Chile y la Santa Sede de 1928". En Mondaca Miranda, Alexis; Aedo Barrena, Cristián (coordinadores), Nuevos horizontes del derecho privado. Santiago: Librotecnia, 428 pp., pp. 123-142. 